\title{
High-resolution paleoclimatic proxy data from the MIS3/2 transition recorded in northeastern Hungarian loess
}

\author{
Janina Bösken ${ }^{\text {a, }}{ }^{*}$, Igor Obreht ${ }^{\mathrm{a}}$, Christian Zeeden ${ }^{\mathrm{a}}$, Nicole Klasen ${ }^{\mathrm{b}}$, Ulrich Hambach ${ }^{\mathrm{c}, \mathrm{d}}$, \\ Pál Sümegi ${ }^{\mathrm{e}}$, Frank Lehmkuhl ${ }^{\mathrm{a}}$ \\ a Department of Geography, RWTH Aachen University, Templergraben 55, 52056 Aachen, Germany \\ ${ }^{\mathrm{b}}$ Institute of Geography, University of Cologne, Albertus-Magnus-Platz, 50923 Cologne, Germany \\ ${ }^{\mathrm{c}}$ BayCEER \& Chair of Geomorphology, University of Bayreuth, Germany \\ d Chair of Physical Geography, Faculty of Sciences, University of Novi Sad, Serbia \\ ${ }^{\mathrm{e}}$ Department of Geology and Palaeontology, University of Szeged, Hungary
}

\section{A R T I C L E I N F O}

\section{Article history:}

Received 31 March 2017

Received in revised form 13 August 2017

Accepted 4 December 2017

Available online 26 December 2017

\section{Keywords:}

Grain size analysis

Weathering indices

Magnetic susceptibility

Loess

Luminescence dating

Wind directions derived from AMS

measurements

\begin{abstract}
A B S T R A C T
The Bodrogkeresztúr loess-paleosol sequence in northeastern Hungary was investigated to improve our understanding of the paleoenvironmental conditions at the foothills of the Carpathians and their impact on the Gravettian population. The main part of the section is comprised of eolian deposits that enable the reconstruction of the paleoenvironmental conditions. This study comprises grain size, geochemical, color and rock magnetic analysis, as well as luminescence and radiocarbon dating. The chronological data place this section from later MIS 3 until present, but also suggest erosion of the sediment in the late MIS 2 and the (early) Holocene. Moreover, generally more humid conditions during late MIS3 and early MIS2 are observed, in comparison to other regions in the Carpathian Basin. Main dust source was most likely the Tisza floodplain, and the material was probably transported to the site from a northeastern wind direction. Increased weathering led to the formation of a well-developed MIS3 paleosol. The loess exhibits elevated values of frequency dependent magnetic susceptibility that highlight the relatively mild conditions during loess formation. Nevertheless, two loess layers with high sand abundance in the profile indicate colder and dryer conditions with increased eolian dynamics during short periods within MIS2. Finally, the Bodrogkeresztúr section highlights the unique microclimatic conditions at the foothill areas of the Carpathian Basin, which may have offered a favorable environment for the Gravettian population.
\end{abstract}

(๑) 2017 Elsevier Ltd and INQUA. All rights reserved.

\section{Introduction}

Loess-paleosol sequences have the ability to preserve past environmental and climatic conditions (e.g. Buggle et al., 2013; Derbyshire, 2003; Evans and Heller, 2001; Guo et al., 2002; Heller and Liu, 1984; Krauß et al., 2016; Kukla, 1977; Kukla et al., 1988; Obreht et al., 2016, 2017; Smalley and Vita-Finzi, 1968; Smalley and Leach, 1978; Zeeden et al., 2016b). Therefore, these represent a widely used terrestrial archive for the reconstruction of paleoclimatic dynamics. The loess deposits of the Carpathian Basin have been studied increasingly in recent years for paleoenvironmental studies, but also for geoarcheological investigations (e.g. Kels et al., 2014; Bösken et al., accepted, Chu et al. accepted). The Danube River

\footnotetext{
* Corresponding author.

E-mail address: Janina.Boesken@geo.rwth-aachen.de (J. Bösken).
}

has been proposed as route for anatomically modern human dispersal in the Middle and Lower Danube Basin, especially during the Aurignacian (Conard and Bolus, 2003, 2008; Mellars, 2011; Iovita et al., 2014). Additionally, the density of Aurignacian find spots suggests a preference for the Carpathian foothill zone (Hauck et al., 2017). Understanding the paleoenvironmental and paleoclimatological conditions during early modern human dispersal might improve our understanding of past human-climate interactions. In northeastern Hungary, there have been also archeological findings of Gravettian origin such as the Bodrogkeresztúr-Henye site (Vértes, 1965, 1966; Dobosi, 2000). Loesspaleosol sequences can be employed to better understand the environmental context of early modern humans by interpreting proxies of weathering intensity (e.g. Újvári et al., 2008; Buggle et al., 2011a; Obreht et al., 2015; Schatz et al., 2015), pedogenesis (e.g. Hao et al., 2008; Bábek et al., 2011), wind strength and directionality (e.g. Nawrocki et al., 2006; Sun et al., 2010; Obreht et al., 2015; 
Zeeden et al., 2015; Újvári et al., 2016), sedimentation rates (e.g. Újvári et al., 2010; Stevens et al., 2011), and changing source material inputs (e.g. Újvári et al., 2012; Muhs et al., 2013; Obreht et al., 2016).

The present study investigates a loess-paleosol sequence close to the former excavations Bodrogkeresztúr-Henye at the Kopasz Hill (see Fig. 1) near Tokaj in northern Hungary. Several proxies (grain size distributions, geochemical analysis, rock magnetic proxies and color measurements) are used to study past environmental changes. Geochronological control is provided by radiocarbon and luminescence dating. The research aim lies in the reconstruction of the paleoenvironmental conditions at the loesspaleosol sequence Bodrogkeresztúr (BKT) in order to improve our understanding of the paleoclimatic conditions in northeastern Hungary specifically in MIS 3 and the transition to the cooler MIS 2. A detailed comparison to the close-by loess-paleosol sequence Tokaj (Sümegi and Hertelendi, 1998; Sümegi, 2005; Schatz et al., 2011, 2012, 2015) aims at detecting local differences in environmental proxies, paleogeography and possibly microclimates. Furthermore, the resolution of the proxy data is increased, which enhances the environmental reconstruction.

\section{Previous investigations}

The investigated Bodrogkeresztúr section is located at the northwestern site of the Kopasz Hill, which contains Sarmatian (Miocene) volcanic (including pyroclastic) rocks and is widely covered by loess deposits (Sümegi and Hertelendi, 1998). Previous investigations around the Kopasz Hill have been conducted intensively (Sümegi and Hertelendi, 1998; Sümegi et al., 2000; Rudner and Sümegi, 2001; Sümegi and Rudner, 2001; Sümegi and Krolopp, 2002; Sümegi, 2005; Schatz et al., 2011, 2012, 2015). The authors constructed a general stratigraphy: the profiles start with a ca. 68-48 ka cal. BP 'lower' loess layer, which probably formed under tundra conditions. It is overlain by a dark brown paleosol (48-41 ka cal. BP), which has evolved under a temperate and humid climate. Above, a 'middle' loess layer ( 41-34 ka cal. BP) is covered by a reddish brown paleosol that formed during the Upper Weichselian 34-29 ka cal. BP (Sümegi and Hertelendi, 1998). The Gravettian layer of the Bodrogkeresztúr-Henye site is also related to this paleosol (Sümegi et al., 2000, 2016). The paleosol is covered by a charcoal bearing white layer indicating the occurrence of extensive (spruce) forest fires under extremely dry conditions $\sim 30-28 \mathrm{ka}$ cal. BP (Sümegi and Hertelendi, 1998; Sümegi et al., 2000; Sümegi and Rudner, 2001; Sümegi, 2005). Overlying this soil is the 'upper' loess layer ( $<29 \mathrm{ka}$ cal. BP) that points to continental steppe conditions. Two interstadial phases within the loess layer were determined at 26-23 and 20-17 ka cal. BP (Sümegi and Hertelendi, 1998), and also two more phases of forest fires occurred around 25 and $20 \mathrm{ka}$ cal. BP. Schatz et al. (2011) found two tree-less steppe intervals with strong winds and loess deposition under cool and humid climate. Moreover, five periods with increased tree/shrub vegetation cover were found in this loess layer.

The new site adds a high-resolution paleoenvironmental archive to the previous investigations that is in the vicinity of the archeological site in a comparable geomorphological position, which allows a reconstruction of the climatological conditions during and after Gravettian occupation. What is more, the original archeological site and it chronological control is disturbed by erosion of the upper loess layer as well as root penetration into the paleosol and the formation of a more recent soil on top of the paleosol (Sümegi and Hertelendi, 1998; Sümegi and Krolopp, 2000; Sümegi et al., 1998, 2000). The new site at the Bodrogkeresztúr brickyard allows investigating an undisturbed paleosol, which can be connected to the archeological site, and its cover loess. Finally, the investigated sequence is the northernmost loess sequence with a thickness $>2 \mathrm{~m}$ in this part of the Carpathians highlighting its value for paleoenvironmental studies.

\section{Methods}

\subsection{Field work}

Two loess-paleosol profiles were carefully cleaned, described, and sampled in a former brickyard close to the town of Bodrogkeresztúr in northeastern Hungary. Samples for rock magnetic, sedimentological and color analyses were taken in a resolution of $4 \mathrm{~cm}$, while geochemical analyses were performed in $8 \mathrm{~cm}$ resolution. One radiocarbon and three luminescence samples were taken at depths of $1.69 \mathrm{~m}$ (C-L3799), $2.9 \mathrm{~m}$ (C-L3797), $4.27 \mathrm{~m}$ (CL3795) and $4.51 \mathrm{~m}$ (Beta-454081). No further charcoal for ${ }^{14} \mathrm{C}$ dating was found.
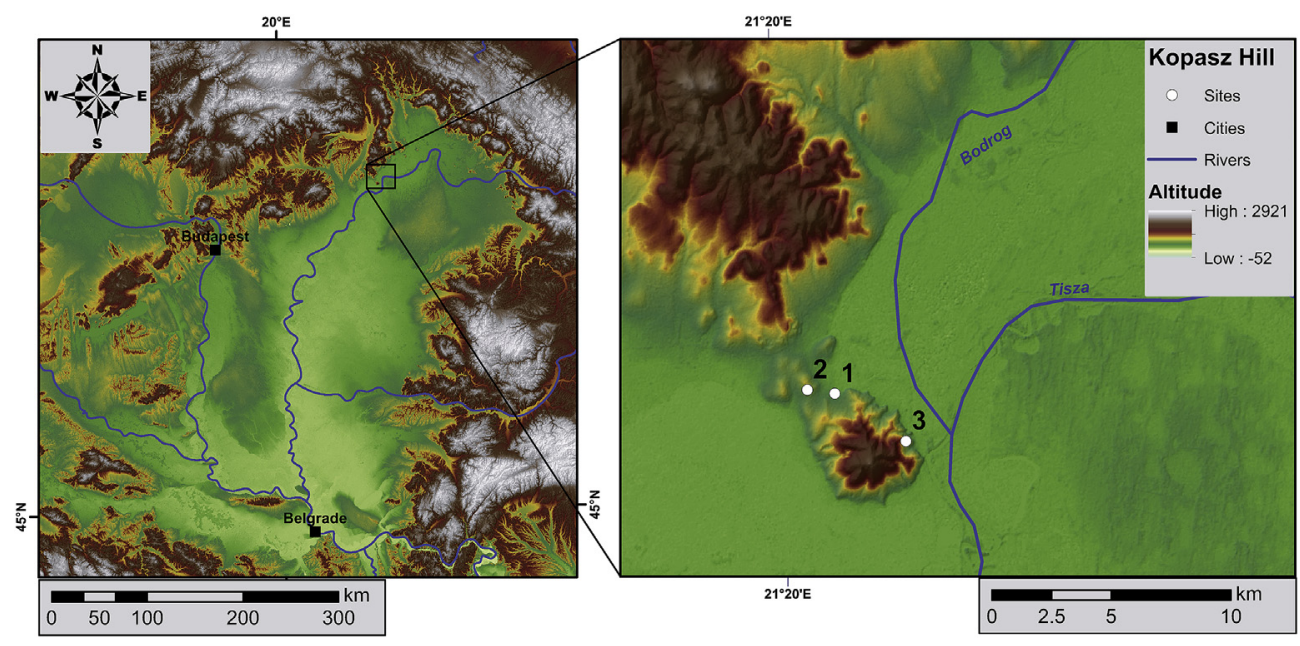

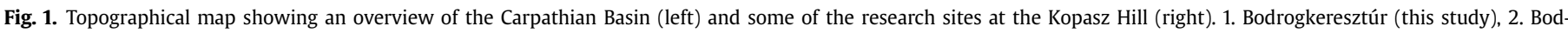

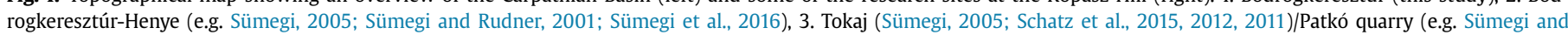
Hertelendi, 1998; Sümegi and Krolopp, 2002). SRTM data available from U.S. Geological Survey. 


\subsection{Geochronology}

\subsubsection{Luminescence dating}

3.2.1.1. Equivalent dose $\left(D_{e}\right)$. Sample preparation for $D_{e}$ determination followed standard laboratory procedures (e.g. Bösken et al., 2017).

Continuous wave optically stimulated luminescence measurements (CW-OSL) were carried out on a Risø TL/OSL DA 20 reader equipped with a ${ }^{90} \mathrm{Sr} /{ }^{90} \mathrm{Y} \beta$ source and IR LEDs, emitting at $870 \mathrm{~nm}$ $(\mathrm{FWHM}=40 \mathrm{~nm})$. For signal detection, a $410 \mathrm{~nm}$ interference filter was used. The applicability of the pIRIR protocol (Thiel et al., 2011; Buylaert et al., 2012) was determined by testing different combinations of preheat, first IR and second IR temperatures on natural and bleached samples (i.e. dose recovery test). First IR stimulation temperature tests on natural samples (cf. Buylaert et al., 2012) were conducted using the pIRIR 225 , pIRIR 250 , pIRIR 270 , and pIRIR 290 protocols. In a second step, selected combinations of preheat, first IR stimulation, and second IR stimulation temperatures underwent a dose recovery test, after the aliquots were bleached for $24 \mathrm{~h}$ in a Hönle Sol2 solar simulator. Finally, the $D_{e}$ was determined on a minimum of eight aliquots per sample using an arithmetic mean. The signal was integrated using the first $2.4 \mathrm{~s}$ minus a background of the last $25.6 \mathrm{~s}$. Residual doses, after bleaching for $24 \mathrm{~h}$ in a Hönle Sol2 solar simulator, were assessed. Fading rates were measured for one sample after administering a dose of 115 Gy using storage times between 100 and 800 min (following Auclair et al., 2003).

3.2.1.2. Dose rate. Samples for dose rate determination were oven dried $\left(50{ }^{\circ} \mathrm{C}\right)$, homogenized and packed into plastic cylinders. Radionuclide concentrations were measured on a high-purity germanium gamma-ray spectrometer after a resting period of four weeks (to compensate for radon emanation during pretreatment). Dose rates and ages were calculated in DRAC v.1.2 (Durcan et al., 2015) using the conversion factors of Liritzis et al. (2013), an estimated water content of $15-17 \%$, and attenuation factors of Bell (1980) and Guérin et al. (2012). The water content was estimated using sample depth and a formula for Hungarian loess sections by Pécsi and Richter (1996). Moreover, an internal potassium content of $12.5 \pm 0.5 \%$ (Huntley and Baril, 1997) and an internal rubidium content of $400 \pm 100$ ppm (Huntley and Hancock, 2001) was assumed. The cosmic dose rate was calculated after Prescott and Hutton (1994) considering the geographical position, altitude and sample depth. $\alpha$-efficiency was determined by giving the samples different $\alpha$-doses of $<400 G y$ in a Freiberg Instruments Lexsyg Research device and recovering this dose with $\beta$-irradiation in a Risø-reader, similar to a dose recovery test. It was ensured that the given dose was small enough to be fitted with a linear function.

\subsubsection{Radiocarbon dating}

The charcoal sample was floated to extract charcoal from sediment. Dating was performed at the Beta Analytic Radiocarbon Dating Laboratory following the acid/alkali/acid-pretreatment procedure. The content of carbon isotopes was measured by means of accelerator mass spectrometry. Finally, the measured carbon isotope ratios were converted to ${ }^{14} \mathrm{C}$ years and later calibrated using the INTCAL13 calibration curve and the intercept method (Talma and Vogel, 1993; Reimer et al., 2013).

\subsection{Rock magnetism}

The rock magnetic measurements followed procedures outlined in e.g. Baumgart et al. (2013), Buggle et al. (2014), and Zeeden et al. (2011, 2015). Samples were dried and compressed into plastic boxes with a volume of $6.4 \mathrm{~cm}^{3}$. Each specimen was measured twice for measurement of the (frequency dependent) magnetic susceptibility $\left(\chi_{\mathrm{fd}}\right)$. Two different frequencies $(0.3$ and $3 \mathrm{kHz})$ in a magnetic $\mathrm{AC}$ field of $300 \mathrm{Am}^{-1}$ and a MAGNON VFSM susceptibility bridge (sensitivity greater than $5 \times 10^{-6} \mathrm{SI}$ ) were used. The frequency dependent magnetic susceptibility is calculated using the following equation: $\chi_{\mathrm{fd}} \%=((\chi 0.3 \mathrm{kHz}-\chi 3 \mathrm{kHz}) / \chi 0.3 \mathrm{kHz}) \times 100$ [\%].

Oriented sampling of nine specimens were taken at a depth range from about 4.02 to $4.12 \mathrm{~m}$. Anisotropy of magnetic susceptibility (AMS) measurements follow procedures outlined in (Zeeden et al., 2011, 2015). Measurements of the magnetic susceptibility and of the anisotropy of the magnetic susceptibility were made employing an AGICO KLY-3S kappabridge. Data evaluation of magnetic fabric data was done employing the ANISOFT software (version 4.2).

\subsection{Grain size (GS)}

For particle size analysis, all samples were prepared as described in Nottebaum et al. (2015) and Schulte et al. (2016). Particle size was measured with a Laser Diffraction Particle Size Analyzer (Beckman Coulter LS 13 320) calculating the percentaged size frequency of 116 classes within a size range of $0.04-2000 \mu \mathrm{m}$ (2\% error). Accuracy was increased by measuring each sample four times in two different concentrations. The grain size distributions were determined using the Mie theory (ISO International Standard 13320, 2009; Fluid RI: 1.33; Sample RI: 1.55; Imaginary RI: 0.1; Özer et al., 2010; cf. Schulte et al., 2016).

\subsection{Geochemistry}

A Spectro Xepos was used for elemental determination by X-ray fluorescence (EDPXRF). Sample preparation followed procedures described in e.g. Kels et al. (2014) and Obreht et al. (2016, 2015). All samples were measured twice and the arithmetic mean is used for data analysis.

Using elemental data, element ratios, such as $\mathrm{Al}_{2} \mathrm{O}_{3} / \mathrm{SiO}_{2}$, were calculated to quantify weathering. The Chemical index of alteration was calculated by using the formula $\mathrm{CIA}=\left(\mathrm{Al}_{2} \mathrm{O}_{3}\right)$ $\left.\left(\mathrm{Al}_{2} \mathrm{O}_{3}+\mathrm{Na}_{2} \mathrm{O}+\mathrm{CaO}^{*}+\mathrm{K}_{2} \mathrm{O}\right)\right)^{*} 100$; where $\mathrm{CaO}^{*}$ is silicatic $\mathrm{CaO}$ (Nesbitt and Young, 1989), as well as the Chemical Proxy of Alteration $\left(\mathrm{CPA}=\left(\mathrm{Al}_{2} \mathrm{O}_{3} /\left(\mathrm{Al}_{2} \mathrm{O}_{3}+\mathrm{Na}_{2} \mathrm{O}\right)\right)^{*} 100\right)$ (Buggle et al., 2011b). Moreover, the $\mathrm{Ba} / \mathrm{Sr}$ ratio was calculated as indicator for immobile (Ba, bound to clay)/mobile ( $\mathrm{Sr}$, similar behavior as $\mathrm{Ca}$ and mainly associated with Ca) elements (see Buggle et al., 2011b and references therein). Additionally, an A-CN-K diagram (Nesbitt and Young, 1989) plots the concentrations of $\mathrm{Al}_{2} \mathrm{O}_{3}, \mathrm{Na}_{2} \mathrm{O}+\mathrm{CaO}^{*}$, and $\mathrm{K}_{2} \mathrm{O}$ in a tertiary diagram.

\subsection{Color}

Samples were homogenized and dried, the color was determined using a Konica Minolta CM-5 spectrophotometer. The L*a*b* values indicate the extinction of light, on a scale from $\mathrm{L}^{*} 0$ (absolute black) to $\mathrm{L}^{*} 100$ (absolute white), and express color as chromaticity coordinates on red-green $\left(\mathrm{a}^{*}\right)$ and blue-yellow $\left(\mathrm{b}^{*}\right)$ scales. Measured colors were plotted using the 'drawProfile.R' $\mathrm{R}$ script (Sprafke, 2016; Zeeden et al., 2017).

\section{Results}

\subsection{Stratigraphy}

The two sampled profiles, about $2 \mathrm{~m}$ apart, can be correlated by means of litho- and pedo-stratigraphy and physical and chemical proxy data (see Supplementary Fig. S1). A composite profile is used for further description (Fig. 2). 


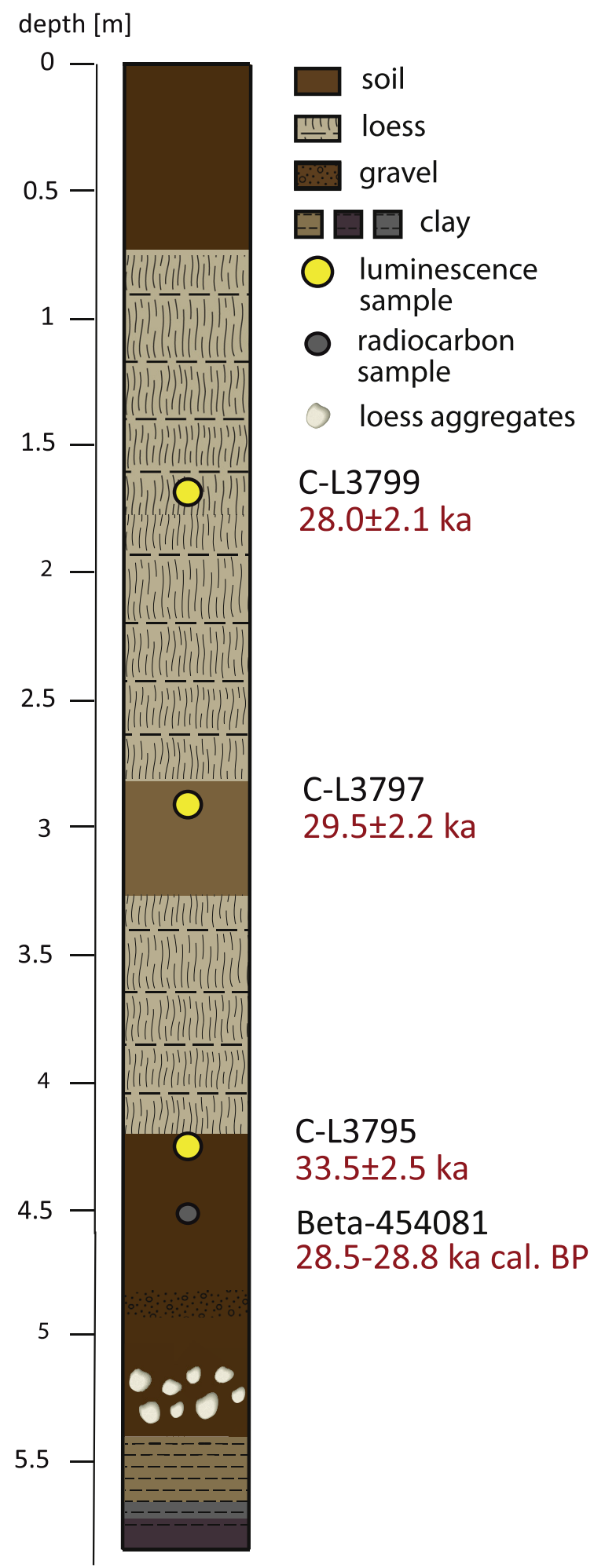

Fig. 2. Stratigraphical sketch of the loess-paleosol sequence Bodrogkeresztúr. Location of geochronological samples and their results are included.

The bottom of the profile is characterized by dark brown $(\sim 5.7-5.84 \mathrm{~m})$ and dark grey clay $(5.67-5.7 \mathrm{~m})$, followed by light and clay-rich sediment (5.45-5.67 m). During fieldwork, the clay layers were interpreted as overbank deposits. Complete mollusk shells were found in the paleosol and loess layers. The clay is followed by a chestnut-colored paleosol $(\sim 4.2-5.45 \mathrm{~m})$. Within this horizon, a layer containing fine gravels $(\sim 4.75 \mathrm{~m})$ and some thin, flat and lens-like loess aggregates (depth 5.1-5.4 m) can be identified. These embedded flat loess aggregates are from a sedimentological perspective interesting, because these are typical for transport over a short distance by water action (cf. Schäfer, 2005). The paleosol is overlain by a horizon of fine grey loess (3.95-4.2 m) with a transitional zone between soil and loess. On top follows a yellowish and homogenous loess layer $(\sim 3.25-3.95 \mathrm{~m})$ and a weak paleosol (2.8-3.25 m). The upper part of the profile is characterized by a homogenous yellowish-light brown loess layer $(0.8-2.8 \mathrm{~m})$ and the modern soil $(0-0.8 \mathrm{~m})$.

\subsection{Geochronology}

\subsubsection{Luminescence data}

Thorough testing of the luminescence signal was undertaken on sample C-L3797. First IR stimulation temperature tests are shown in Fig. 3a. Four pIRIR protocols with a second stimulation temperature of $225{ }^{\circ} \mathrm{C}, 250{ }^{\circ} \mathrm{C}, 270{ }^{\circ} \mathrm{C}$, and $290{ }^{\circ} \mathrm{C}$ were tested. While preheat temperatures were always $30^{\circ} \mathrm{C}$ higher than second IR stimulation temperatures, different first IR stimulation temperatures were applied: $50{ }^{\circ} \mathrm{C}, 80^{\circ} \mathrm{C}, 110{ }^{\circ} \mathrm{C}, 140{ }^{\circ} \mathrm{C}$ and $180^{\circ} \mathrm{C}$. Additionally, we
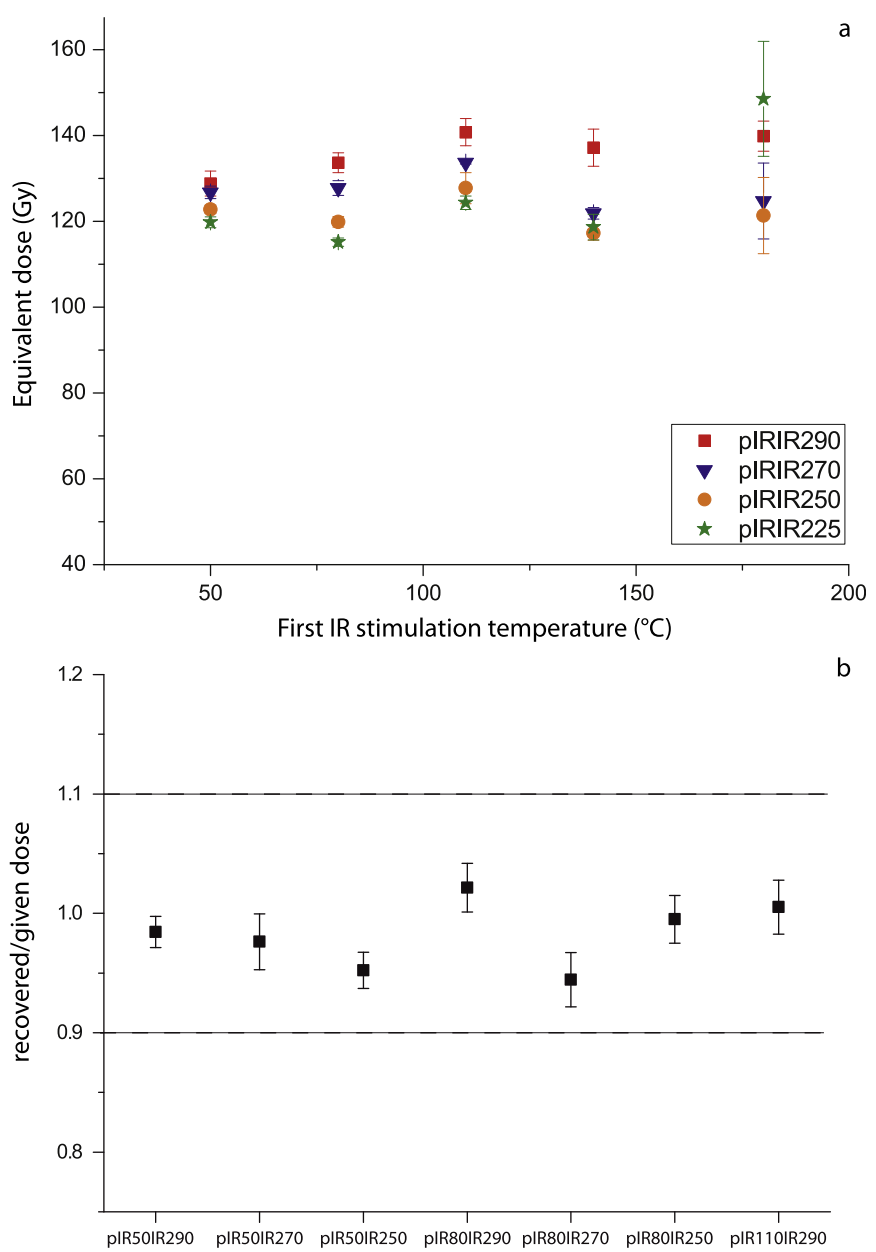

Fig. 3. a.) Plot showing the results of the first IR stimulation temperature tests on sample C-L3797. Four different pIRIR protocols were used with second IR stimulation temperatures of $225^{\circ} \mathrm{C}, 250^{\circ} \mathrm{C}, 270^{\circ} \mathrm{C}$, and $290^{\circ} \mathrm{C}$. Tested first IR temperatures were $50^{\circ} \mathrm{C}, 80^{\circ} \mathrm{C}, 110^{\circ} \mathrm{C}, 140^{\circ} \mathrm{C}$, and $180^{\circ} \mathrm{C}$. b.) Dose recovery test of sample C-L3797 using different combinations of preheat, first IR and second IR stimulation temperatures. Preheat temperatures were always $30^{\circ} \mathrm{C}$ higher than second IR stimulation temperatures. All tested pIRIR protocols pass the test with an acceptance limit of $1.0 \pm 0.1$. 
conducted a dose recovery test (Fig. 3b) for some of the tested protocols, which shows that all tested protocols are able to recover a given dose satisfactorily (recovered/given dose ratios between $0.95 \pm 0.02$ and $1.02 \pm 0.02$ ). In order to keep fading to a minimum and allow a better comparison to other samples measured, we finally used the $\mathrm{pIR}_{50} \mathrm{IR}_{290}$ protocol for $\mathrm{D}_{\mathrm{e}}$ determination. Fig. $\mathrm{S} 2$ in the Supplementary Materials shows several shine down and dose response curves. The abanico plots (Fig. S3) indicate a low relative standard error $<4 \%$ for all $D_{e}$ distributions. Residual signals after $24 \mathrm{~h}$ bleaching are minimal ( $<5 \mathrm{~Gy}$ ) and were not considered for further calculations. Alpha efficiency measurements determined avalues of $0.13 \pm 0.02$ (C-L3795) and $0.12 \pm 0.02$ (C-L3797 and CL3799). The fading measurements determined a mean $\mathrm{g}_{2 \text { days }}$ value of $0.27 \pm 0.76 \%$ for sample C-L3797 (Fig. S4). Dose rates are similar for all samples $\sim 4.1 \mathrm{~Gy} / \mathrm{ka}$. Final ages and $\mathrm{D}_{\mathrm{e}}$ values increase with depth from $28.0 \pm 2.1 \mathrm{ka}(115.8 \pm 6.0 \mathrm{~Gy})$ to $33.5 \pm 2.5 \mathrm{ka}$ $(139.8 \pm 7.1 \mathrm{~Gy})$. Table 1 summarizes the luminescence data.

\subsubsection{Radiocarbon dating}

Sample Beta-454081 yields a conventional radiocarbon age of $24,580 \pm 90$ BP. $2-\sigma$ confidence interval of the calibrated age is $28,770-28,475$ cal. BP. At a $1-\sigma$ confidence interval, the calibrated age estimate is $28,705-28,565$ cal. BP.

\subsection{Rock magnetism}

The magnetic susceptibility $(\chi)$ of the profile ranges from 30 to $90^{*} 10^{-8} \mathrm{~m}^{3} / \mathrm{kg}$ (Fig. 4). The lower $\sim 1.5 \mathrm{~m}$ of the profile show considerable variability starting with a decrease from $\sim 90^{*} 10^{-8} \mathrm{~m}^{3} /$ $\mathrm{kg}$ to $40^{*} 10^{-8} \mathrm{~m}^{3} / \mathrm{kg}$ within $30 \mathrm{~cm}$. This is followed by a less rapid increase in $\chi$ towards $\sim 70^{*} 10^{-8} \mathrm{~m}^{3} / \mathrm{kg}$ (4.6 m depth). Another rapid decrease in $\chi$ towards $\sim 35^{*} 10^{-8} \mathrm{~m}^{3} / \mathrm{kg}$ is succeeded by a double sigmoidal pattern at a depth from 2.7 to $4.1 \mathrm{~m}$. Above, $\chi$ decreases slightly and shows only small variation between 30 and $40^{*} 10^{-8} \mathrm{~m}^{3} / \mathrm{kg}$ in the upper part of the profile $(\sim 0.32-2.0 \mathrm{~m})$. The frequency dependent magnetic susceptibility $\left(\chi_{\mathrm{fd}}\right)$ begins with values around $12 \%$ in the lower $\mathrm{cm}$, which drop rapidly toward $8-10 \%(4.2-5.5 \mathrm{~m})$. After a minimum $~ 5 \%$ (3.4-4.1 $\mathrm{m})$, the upper $3.4 \mathrm{~m}$ show similar values around $\sim 6-7 \%$, however, some variations are observed, especially at $1.2 \mathrm{~m}$ and $1.75 \mathrm{~m}$ depth.

The magnetic susceptibility is often measured in bulk, but its (an)isotropy can be investigated when turning samples 3directional in an applied field. This yields a 3-dimensional ellipsoid, which can be fully described by its orientation and three axis lengths of the maximum, medium and minimum susceptibility. In sedimentary systems, anisotropic particles are often lying flat, and also preferential directions can be observed and interpreted.

Here, the axes of maximum susceptibility (k1; circles in Fig. 5) have a mean declination of $176.4^{\circ}( \pm 33.2)$ and inclination of $1.9^{\circ}$ $( \pm 9.1)$. The axis of medium susceptibility (k2; triangles) have a mean declination of $266.6^{\circ}( \pm 33.3)$ and inclination of $4.7^{\circ}( \pm 6.1)$. The minimum (k3; squares) axis of data have a mean declination of $64.8^{\circ}( \pm 9.2)$ and a mean inclination of $84.9^{\circ}( \pm 6.3)$.

Confidence in clear separation of a maximum, medium and minimum axis can be reached through parametric (Jelinek, 1977) and nonparametric statistics (Constable and Tauxe, 1990), here the test according to Jelinek (1977) is applied. All tests for anisotropy (mean F-test value is 237) and rotational anisotropy (mean F test value is 42) show that anisotropy could be determined from all but two (T_2.1; T_6.3) samples. Fig. 5 shows all data, and encircles the k1 \& k2 directions for the two samples where these directions cannot be reliably separated. However, their consistency with remaining samples suggests the correct assignment of $k 1$ and $k 2$ directions.

\subsection{Grain size}

Fig. 6 shows the changes in grain size throughout the sequence. At the bottom of the profile fine and coarse silts $(<5 \mu \mathrm{m} ; 22-63 \mu \mathrm{m})$ are the most abundant fractions ( $60 \%)$, while grains $>63 \mu \mathrm{m}$ show the smallest proportion of $\sim 5 \%$. Between 3.8 and $5.2 \mathrm{~m}$ the coarser fractions increases at varying rates up to $75 \%$, while the finer fractions decrease accordingly. A double sigmoidal pattern is evident for all grain size fractions at $2.8-3.8 \mathrm{~m}$ depth. The upper part of the section $(0-2.8 \mathrm{~m})$ is characterized by increasing percentages of the fine grain sizes from $\sim 15 \%$ to $20 \%(<5 \mu \mathrm{m})$ and from $17 \%$ to $24 \%$ (5-22 $\mu \mathrm{m}$; Fig. 6 ). The coarser grain sizes show an increasing trend in this part (50-45\% for $22-63 \mu \mathrm{m}$; $19-10 \%$ for $>63 \mu \mathrm{m})$, with the maximum in sand $(>63 \mu \mathrm{m})$ between 1.3 and $1.8 \mathrm{~m}$.

The U-ratio shows a similar pattern as the coarse grain sizes. It shows a low value of $1.5-2.2$ in the bottom of the profile $(4.5-5.84 \mathrm{~m})$. The U-ratio increases rapidly between $\sim 4$ and $4.5 \mathrm{~m}$ towards 4 and shows the same double sigmoidal pattern as the coarse grain sizes between 2.7 and $4 \mathrm{~m}$. The U-ratio is relatively constant between 2 and $\sim 2.5 \mathrm{~m}$ around 3.5 and decreases slowly in the upper $2 \mathrm{~m}$ of the profile towards 2.5 .

The grain size distribution curves of loess show a bimodal distribution of the sediment with a pronounced peak in the coarse silt fraction and a shoulder in the clay (Fig. 7). The well-developed basal paleosol also shows a bimodal grain size distribution, where the pronounced peak has a lower volume and the shoulder in clay has a more pronounced volume. The lowermost $0.2 \mathrm{~m}$ of the section are not characterized by bimodal distributions.

\subsection{Geochemistry}

The sediment is dominated by quartz being the major carrier of $\mathrm{SiO}_{2}$, contributing from 65.8 to $70.7 \%$, except in the lowermost $12 \mathrm{~cm}$ of the section where the $\mathrm{SiO}_{2}$ abundance shows lower values between 56 and $62 \%$ (Fig. 8). The $\mathrm{Al}_{2} \mathrm{O}_{3}$ content shows an average of $15.1 \%$. $\mathrm{CaO}$ is generally low for Danubean loess (average $4.4 \%$; compare Bösken et al., accepted; Krauß et al., 2016; Obreht et al., 2016,2015 ), with an abundance of $\sim 10 \%$; only in the lower $12 \mathrm{~cm}$ values increase up to $\sim 18 \%$. Albeit the general values are low, the lower $20 \mathrm{~cm}$ exhibit high fluctuations between 0.9 and $18 \%$ (Fig. 8). The sediments contain $4.9 \% \mathrm{FeO}$ with slightly higher values in the lower part (paleosol) of 5-5.5\%. The average content of $\mathrm{P}_{2} \mathrm{O}_{5}$ is $0.2 \%$, its abundance decreases gradually in the paleosol towards $0.11 \% . \mathrm{Cl}$ shows low values $<30 \mathrm{ppm}$ for most of the profile, except in

Table 1

Luminescence data including radionuclide concentrations, dose rates (DR), equivalent doses, alpha efficiency and age.

\begin{tabular}{|c|c|c|c|c|c|c|c|c|c|c|c|}
\hline $\begin{array}{l}\text { Sample } \\
\text { Code }\end{array}$ & $\begin{array}{l}\text { Grain size } \\
(\mu \mathrm{m})\end{array}$ & $\begin{array}{l}\text { Depth } \\
(\mathrm{m})\end{array}$ & $\begin{array}{l}\text { No. of } \\
\text { aliquots }\end{array}$ & $\begin{array}{l}\mathrm{D}_{\mathrm{e}}(\mathrm{Gy}) \\
\text { mean }\end{array}$ & $\begin{array}{l}\text { Residual } \\
\text { (Gy) }\end{array}$ & $\mathrm{U}(\mathrm{ppm})$ & Th (ppm) & $\mathrm{K}(\%)$ & $\begin{array}{l}\text { Alpha } \\
\text { efficiency }\end{array}$ & $\begin{array}{l}\text { Water cont. (\%) } \\
\text { calculated }\end{array}$ & $\begin{array}{l}\text { Total DR Age (ka) } \\
(\mathrm{Gy} / \mathrm{ka})\end{array}$ \\
\hline C-L3799 & $4-11$ & 1.69 & $9 / 9$ & $115.8 \pm 6.0$ & $4.09 \pm 0.5$ & $2.51 \pm 0.13$ & $10.18 \pm 0.6$ & $1.61 \pm 0.02$ & $0.12 \pm 0.02$ & $15.0 \pm 5$ & $4.14 \pm 0.228 .0 \pm 2.1$ \\
\hline C-L3797 & $4-11$ & 2.90 & $9 / 9$ & $122.5 \pm 6.4$ & $4.13 \pm 0.3$ & $2.63 \pm 0.14$ & $10.29 \pm 0.6$ & $1.60 \pm 0.02$ & $0.12 \pm 0.02$ & $15.8 \pm 5$ & $4.14 \pm 0.229 .6 \pm 2.2$ \\
\hline C-L3795 & $4-11$ & 4.27 & $10 / 10$ & $139.8 \pm 7.1$ & $4.73 \pm 0.3$ & $2.58 \pm 0.14$ & $10.69 \pm 0.6$ & $1.53 \pm 0.02$ & $0.13 \pm 0.02$ & $16.6 \pm 5$ & $4.18 \pm 0.233 .5 \pm 2.5$ \\
\hline
\end{tabular}




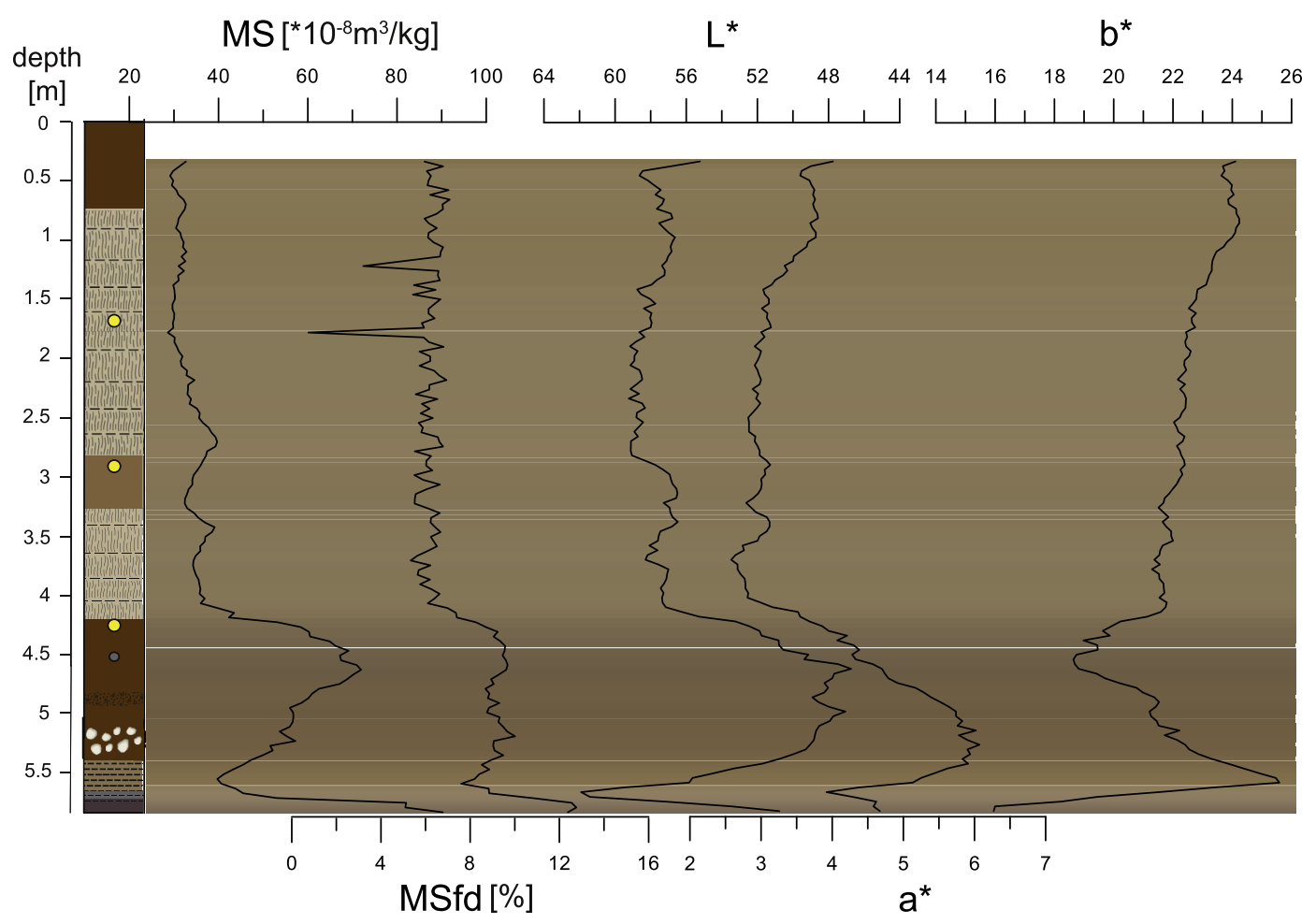

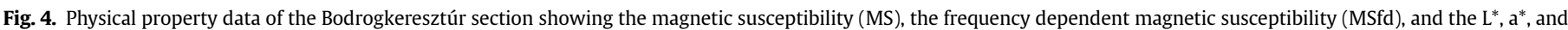

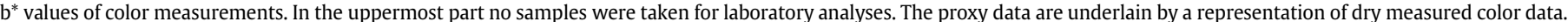
(For interpretation of the references to color in this figure legend, the reader is referred to the Web version of this article.)

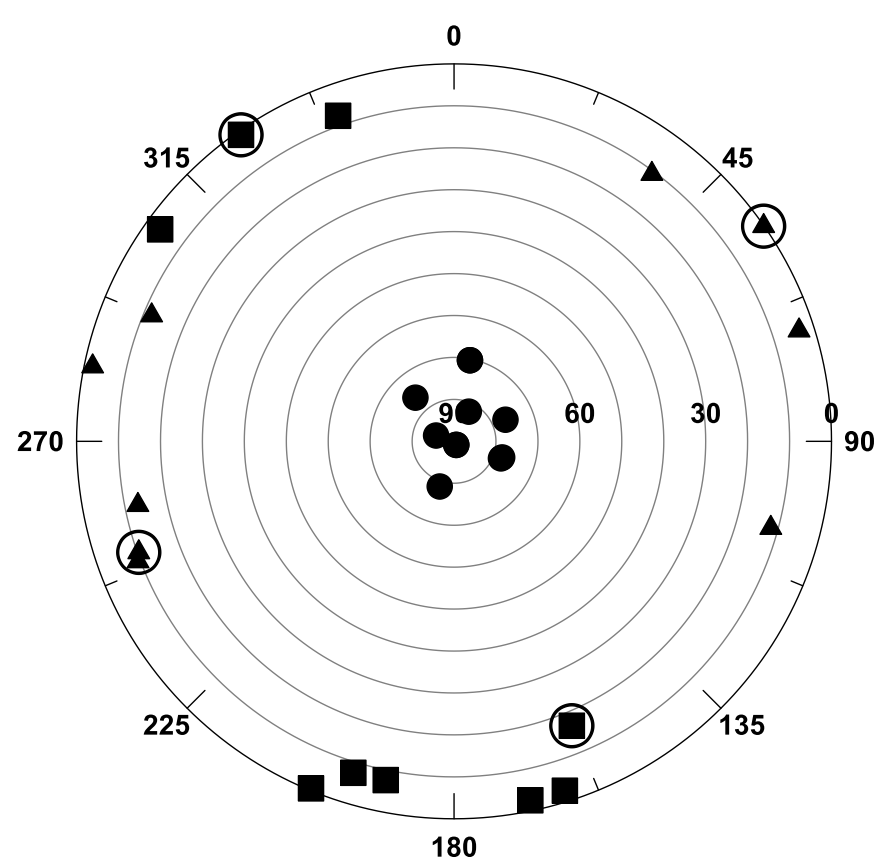

Fig. 5. Directions of the anisotropy of the magnetic susceptibility from Bodrogkeresztúr. Circles depict k3 directions, triangles depict k2 directions and squares represent $\mathrm{K} 1$ axes. Encircled data indicates that k1 and k2 directions cannot clearly be separated statistically.

2.1-2.8 m, where a sudden increase towards $605 \mathrm{ppm}$ is observed.

Fig. 9 shows the geochemical ratios and weathering indices. The lowermost $\sim 20 \mathrm{~cm}$ show a strong variability in weathering indices. Generally, the weathering indices CIA and CPA follow an upward- decreasing trend with varying values between 64 and 74 (CIA), and 85-91 (CPA). $\mathrm{Rb} / \mathrm{Sr}$ and $\mathrm{Ba} / \mathrm{Sr}$ follow a similar general pattern. Decreasing values from $5.5 \mathrm{~m}$ to $4 \mathrm{~m}(0.9$ for $\mathrm{Rb} / \mathrm{Sr}$ and 4 for $\mathrm{Ba} / \mathrm{Sr})$ are followed by pronounced minima from ca. 4-2.4 $\mathrm{m}$ depth. Increasing values occur in the upper $\sim 2.5 \mathrm{~m}(0.85-0.65$ for $\mathrm{Rb} / \mathrm{Sr}$; 4-2.8 for $\mathrm{Ba} / \mathrm{Sr})$. The $\mathrm{Al}_{2} \mathrm{O}_{3} / \mathrm{SiO}_{2}$ ratio is elevated in the paleosol ( 0.24) and shows lowest values between 2.8 and $4.2 \mathrm{~m}(0.2-0.21)$. The upper $1.5 \mathrm{~m}$ show an increasing trend of $\mathrm{Al}_{2} \mathrm{O}_{3} / \mathrm{SiO}_{2}$ towards 0.23 .

The $\mathrm{A}-\mathrm{CN}-\mathrm{K}$ diagram $\left(\mathrm{Al}_{2} \mathrm{O}_{3}-\left(\mathrm{CaO}^{*}+\mathrm{Na}_{2} \mathrm{O}\right)-\mathrm{K} 2 \mathrm{O}\right.$ diagram; Nesbitt and Young, 1984) in Fig. 10 informs about weathering and sorting effects of aluminosilicates, as well as the initial composition of the unweathered material (Buggle et al., 2008; Obreht et al., 2015). At the Bodrogkeresztúr section, all samples are clustered on the line parallel to the $\mathrm{A}-\mathrm{CN}$ join, indicating a domination of the chemical weathering (first-order plagioclase removal, and slight $\mathrm{K}$ feldspar weathering) and an absence of a sediment sorting effect at the section.

\subsection{Color}

Measured colors were plotted in Fig. 4. Values of $\mathrm{L}^{*}$ (extinction of light) and $\mathrm{a}^{*}$ (red-green) show a similar pattern (note that $\mathrm{L}^{*}$ is plotted from higher to smaller values): $\mathrm{L}^{*}$ value range from 48 to 64 with lowest values in the lowermost sample and between 4.2 and $5.3 \mathrm{~m}$. The highest $\mathrm{L}^{*}$ values of $\sim 64$ occur at a depth of $\sim 5.7 \mathrm{~m}$. In the upper $4 \mathrm{~m}, \mathrm{~L}^{*}$ values range from 54 to 59 , with slightly lower values in the interval between 2.8 and $4.1 \mathrm{~m}^{*}$ shows an opposite pattern with minima around $3(2.8-4.1 \mathrm{~m})$ and a maximum of $\sim 6$ (4.9-5.3 m). a* shows values $\sim 3-3.5$ between 1.4 and $4.1 \mathrm{~m}$ and increases in the upper $1 \mathrm{~m}$ towards 4 . $\mathrm{b}^{*}$ shows a rapid increase from 15 to 25 between $5.6 \mathrm{~m}$ and $5.84 \mathrm{~m}$ depth, which is followed by decreasing values towards $18(4.5 \mathrm{~m})$. b* increases first rapidly 


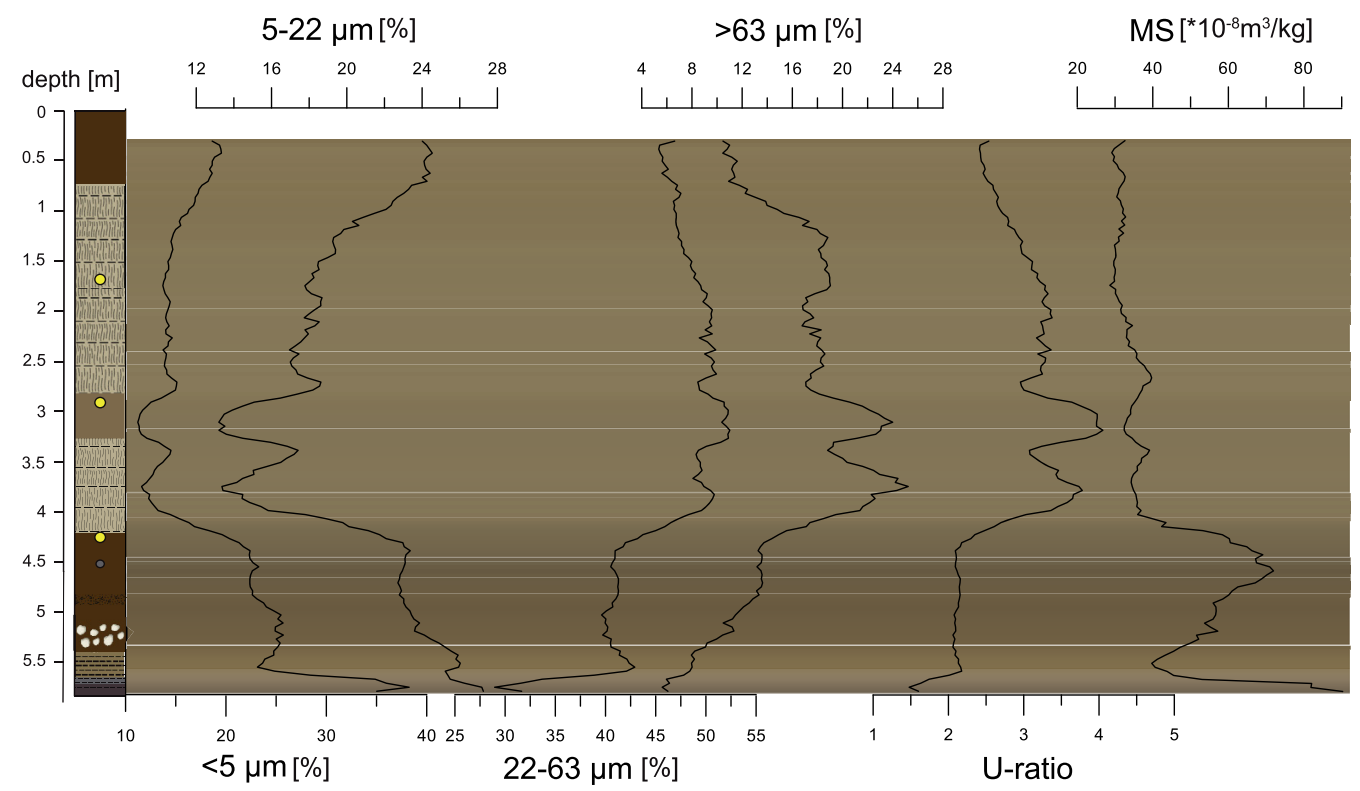

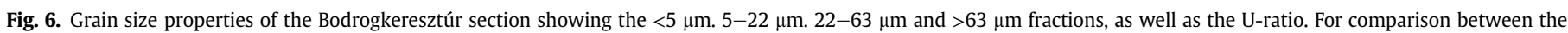
figures the magnetic susceptibility (MS) is shown. In the uppermost part no samples were taken for laboratory analyses.

and then more gradually towards 24 until the top of the section.

\section{Discussion}

\subsection{Geochronology}

The luminescence samples were tested thoroughly to choose the optimal measurement settings. The dose recovery ratios, low fading rates, and low relative standard errors confirm the applicability of the used pIR ${ }_{50} I_{290}$ protocol. The luminescence data fits well to the radiocarbon chronology of the Kopasz hill (Sümegi and Hertelendi, 1998) and the luminescence chronology of Schatz et al. (2012). The Bodrogkeresztúr section can be linked to the 'upper' paleosol and the 'upper' loess layer found at the other profiles. Our age of $33.5 \pm 2.5 \mathrm{ka}$ (C-L3795) agrees well with two pIRIR 290 ages of $39.2 \pm 3.4 \mathrm{ka}$ and $30.1 \pm 2.7 \mathrm{ka}$ of the upper paleosol at Tokaj (Schatz et al., 2012). In addition, the radiocarbon chronology (Sümegi and Hertelendi, 1998) places this paleosol between 29 and $34 \mathrm{ka}$ cal. BP. Moreover, the other two ages of $28.0 \pm 2.1$ and $29.6 \pm 2.2 \mathrm{ka}$ fall in the same range as the upper loess layer at Tokaj, which is dated to $24.9 \pm 2.2-27.8 \pm 2.5 \mathrm{ka}$ (Schatz et al., 2012). . The radiocarbon sample gives an age of 28.5-28.8 ka cal. BP, and represents an age estimate of the formation of the paleosol slightly younger than the age of the sedimentation as dated by the luminescence samples. However, this is not surprising as not the same event is dated and age estimates do overlap when their $2-\sigma$ uncertainty are considered. Similar observations were made by Újvári et al. (2014a) at the Dunaszekcső loess paleosol sequence where pIRIR 290 age estimates were consistently older than ${ }^{14} \mathrm{C}$ ages, especially in younger samples.

Even though resulting ages agree well between the BKT and Tokaj profiles, there are considerable differences in the luminescence characteristics, which might speak for different provenance, geochemistry or sedimentary processes prior to deposition. At Tokaj, Schatz et al. (2012) encountered severe problems during the dose recovery measurements related to the optical or thermal pretreatment, while the BKT samples did not show any problematic behavior. Residual doses are higher at Tokaj, but both sections show in general low residuals. In both sections, residual doses increase slightly with the equivalent dose. Dose rates at Tokaj were marginally lower than at BKT, and different a-values were used, which can lead to differences in age of a few thousand years.

\subsection{Origin of the sediments}

The bimodal grain size distribution curves of loess with a peak in coarse silt and a shoulder in clay strongly support an eolian origin of the sediments, although a minor contribution of slope wash deposits cannot be ruled out. The well-developed basal paleosol shows a bimodal distribution with exception of the lowermost $0.2 \mathrm{~m}$, suggesting a mixing of loess-like and alluvial deposits here. This is supported by observations in the field and low values of $\chi$ ( $4.6 \mathrm{~m}$ to bottom). Therefore, the part below a depth of $4.6 \mathrm{~m}$ should not be interpreted as a paleoclimatic signal.

Wind directions inferred from AMS measurements (e.g. Nawrocki et al., 2006; Bradák, 2009; see Fig. 5) speak for a dominant north(west) - south(east) wind direction, or a perpendicular direction from (south)west - (north)east (for the eolian part of the section). A paleowind direction of north-south direction may also be inferred from landforms in the region and to the south-east in the more open steppe landscape. Here we interpret the data as the material originating from a predominantly northeastern wind direction, because this is most consistent with landforms in the region (visible in topographic maps). This suggests the Tisza floodplain to the northeast to be a main source of sediment, which is supported by an increased abundance of coarser particles (Fig. 6) indicating that the source area was close by (Obreht et al., 2014, 2016; Bösken et al., accepted). However, the well-developed paleosol shows a high abundance of fine particles, suggesting a strong alteration of primary deposited loess caused by pedogenesis, combined with the deposition of fine-grained overbank deposits.

Geochemical characteristics (Fig. 8) show a composition similar to the Tokaj section, with a higher contribution of $\mathrm{SiO}_{2}$ and a lower contribution of $\mathrm{CaO}$. This is different to other studied loess sections in Hungary (Újvári et al., 2008, 2014b; Varga et al., 2011; Bösken et al., accepted), indicating strong dissolution of $\mathrm{CaO}$ from the original sediment, also supported by low $\mathrm{Sr}$ values (average $111 \mathrm{ppm}$ ). Moreover, $\chi$ and $\chi_{\mathrm{fd}}$ are generally high for Danubean 

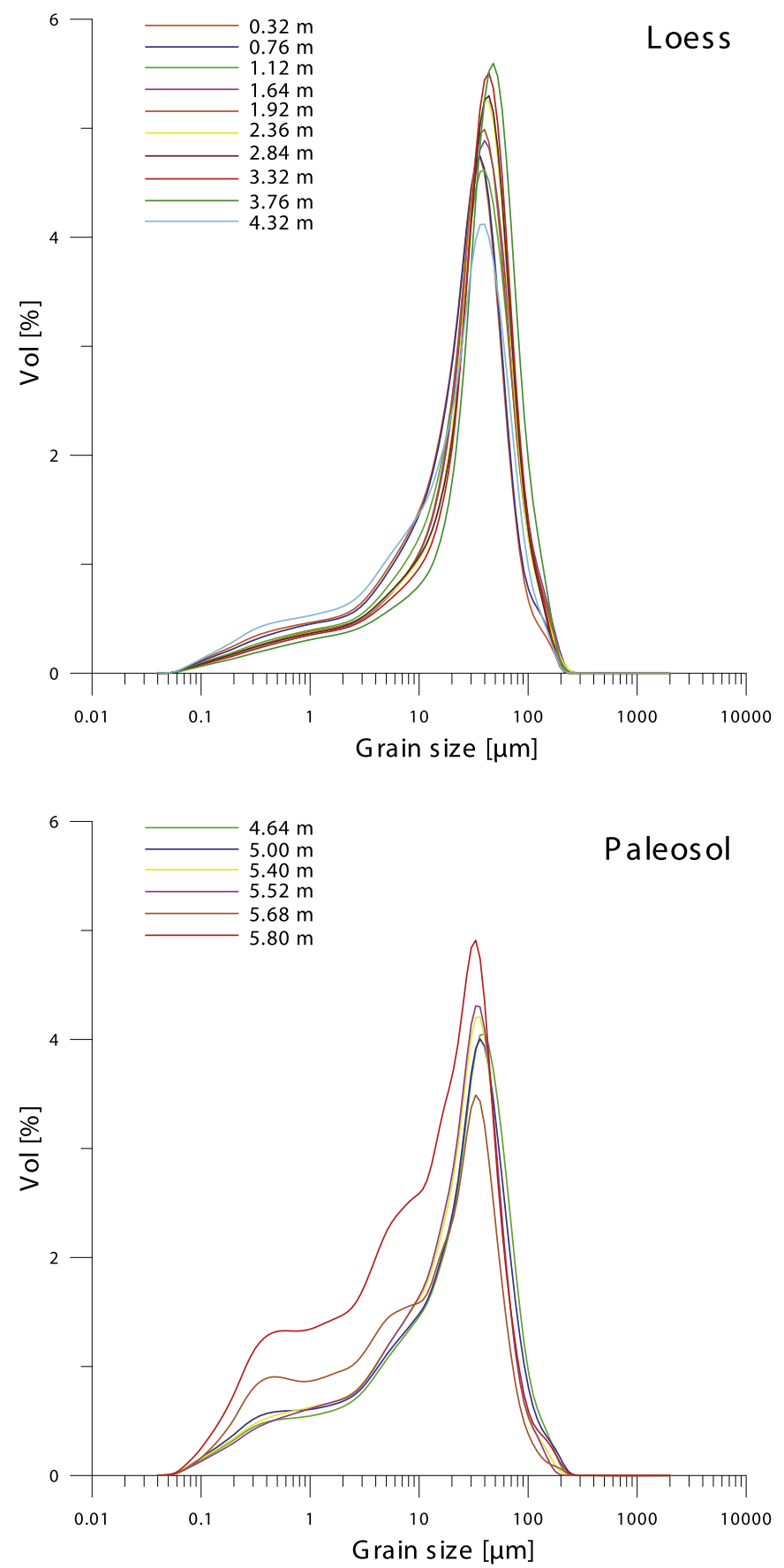

Fig. 7. Grain size density distribution curves of representative samples from different stratigraphic depths.

loess, additionally supporting the interpretation of increased weathering intensity caused by relatively high paleo-precipitation. Also low $\mathrm{L}^{*}$ and high $\mathrm{a}^{*}$ values (in comparison to other loess sections in Southeastern Europe, e.g. Bösken et al., accepted; Lukić et al., 2014; Obreht et al., 2016) indicate a generally high intensity of pedogenesis and weathering.

\subsection{Weathering indices}

Chemical weathering indices have been widely applied to evaluate the intensity of weathering in loess from different regions (Yang et al., 2006; Varga et al., 2011; Buggle et al., 2011b, 2013;
Újvári et al., 2014b; Hošek et al., 2015; Krauß et al., 2016; Obreht et al., 2015). They are based on the concept on mineral alteration, where the selective removal of soluble and mobile elements from a section is compared to a relative enrichment of immobile and nonsoluble elements. Simple ratios like $\mathrm{Ba} / \mathrm{Sr}$ or $\mathrm{Rb} / \mathrm{Sr}$ are suggested to be strongly influenced by $\mathrm{CaCO}_{3}$ content (Buggle et al., 2011b), or rarely by $\mathrm{MgO}$ content (Obreht et al., 2015). However, Schatz et al. (2015) reported those ratios to be influenced by the grain size rather than $\mathrm{CaCO}_{3}$ content at Tokaj. Similarly, the $\mathrm{Ba} / \mathrm{Sr}$ and $\mathrm{Rb} / \mathrm{Sr}$ ratios from our record show a similar trend like the fine fractions (Fig. 9). An explanation of such grain size dependence of geochemical ratios may be related to higher $\mathrm{Rb}$ concentrations in clay and enrichment of the Sr in silt (Schatz et al., 2015; Újvári, 2014). Nevertheless, additional studies are required for a better understanding of the nature of the $\mathrm{Ba} / \mathrm{Sr}$ and $\mathrm{Rb} / \mathrm{Sr}$ ratios as weathering indices. Classical weathering indices like the Chemical Index of Alteration (CIA, Nesbitt and Young, 1989) or the Chemical Proxy of Alteration (CPA, Buggle et al., 2011b) are suggested to be more sensitive to the weathering intensity. However, studies with a higher sampling resolution (Obreht et al., 2015; Krauß et al., 2016) demonstrated that the general trends of the CIA and CPA are mostly in agreement with enhanced weathering, but clear deviations are observed in some parts of the profiles. Similarly, the CIA and CPA from the Bodrogkeresztúr section indicate increased weathering in the well-developed paleosol and the upper part of the section, but the values between 2 and $3.5 \mathrm{~m}$ show high values that are not supported by other proxies that represent weathering (cf. Fig. 9). A potential explanation for this discrepancy is that weathering indices, such as $\mathrm{Rb} / \mathrm{Sr}$ and $\mathrm{Ba} / \mathrm{Sr}$ ratios, may be controlled by grain size and leaching, while CIA and CPA might preferentially reflect $\mathrm{Ca}$ and Na removal by plagioclase and feldspar weathering.

\subsection{Paleoclimatological conditions during late MIS3}

Geochemical characteristics of the Bodrogkeresztúr section show clear differences between loess and paleosol. The welldeveloped paleosol with a supposed alluvial sediment input at the profile base has higher $\mathrm{FeO}$ and $\mathrm{Al}_{2} \mathrm{O}_{3}$ contents (Fig. 8), suggesting strong weathering producing iron oxides and finer particles associated with a higher Al contribution due to post-depositional clay formation.

The unusually well-developed MIS 3 paleosol is a characteristic of both sections, Tokaj and Bodrogkeresztúr, indicating rather humid conditions during MIS 3 in the northern part of the Carpathian Basin. Values of $\chi$ in this paleosol (cf. Fig. 4) are in the range of the values from interglacial soils in the other parts of the Carpathian Basin (Buggle et al., 2009, 2014; Marković et al., 2011; Stevens et al., 2011; Újvári et al., 2016; Zeeden et al., 2016b), supporting an interpretation of high humidity and enhanced soil moisture. This is also supported by high values of $\chi_{\mathrm{fd}}$ in the paleosol (cf. Fig. 4). Moreover, dark soil color suggests a high concentration of humic material and therefore, strong pedogenesis over this period.

Lower values of weathering indices of the Tokaj section, when compared to Bodrogkeresztúr, also indicate weaker weathering at the higher geomorphological position. Consequently, the different geomorphological situated sections of Tokaj and Bodrogkeresztúr did experience slightly different local paleoenvironmental conditions; however, both profiles show that paleoclimatic conditions were more humid than in the remaining Carpathian Basin.

\subsection{Paleoclimatological conditions during early MIS2}

The $\chi_{\mathrm{fd}}$ also shows higher values in loess (MIS 2) in comparison to other loess sections of the same period. Values are in the range usually found in MIS 3 paleosols of the Carpathian Basin, or even 


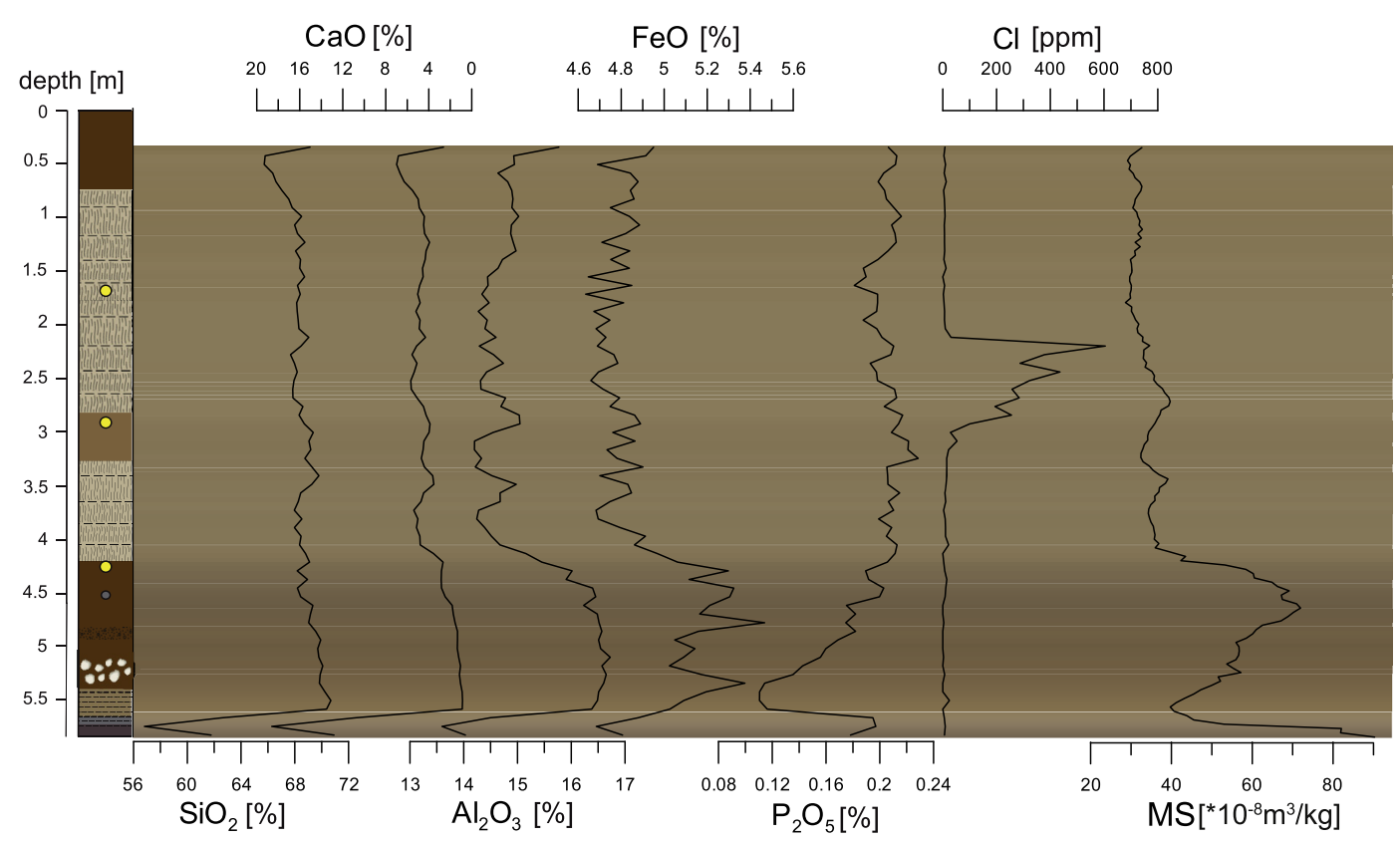

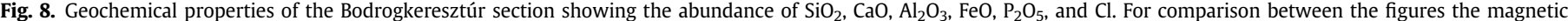
susceptibility (MS) is shown. In the uppermost part no samples were taken for laboratory analyses.

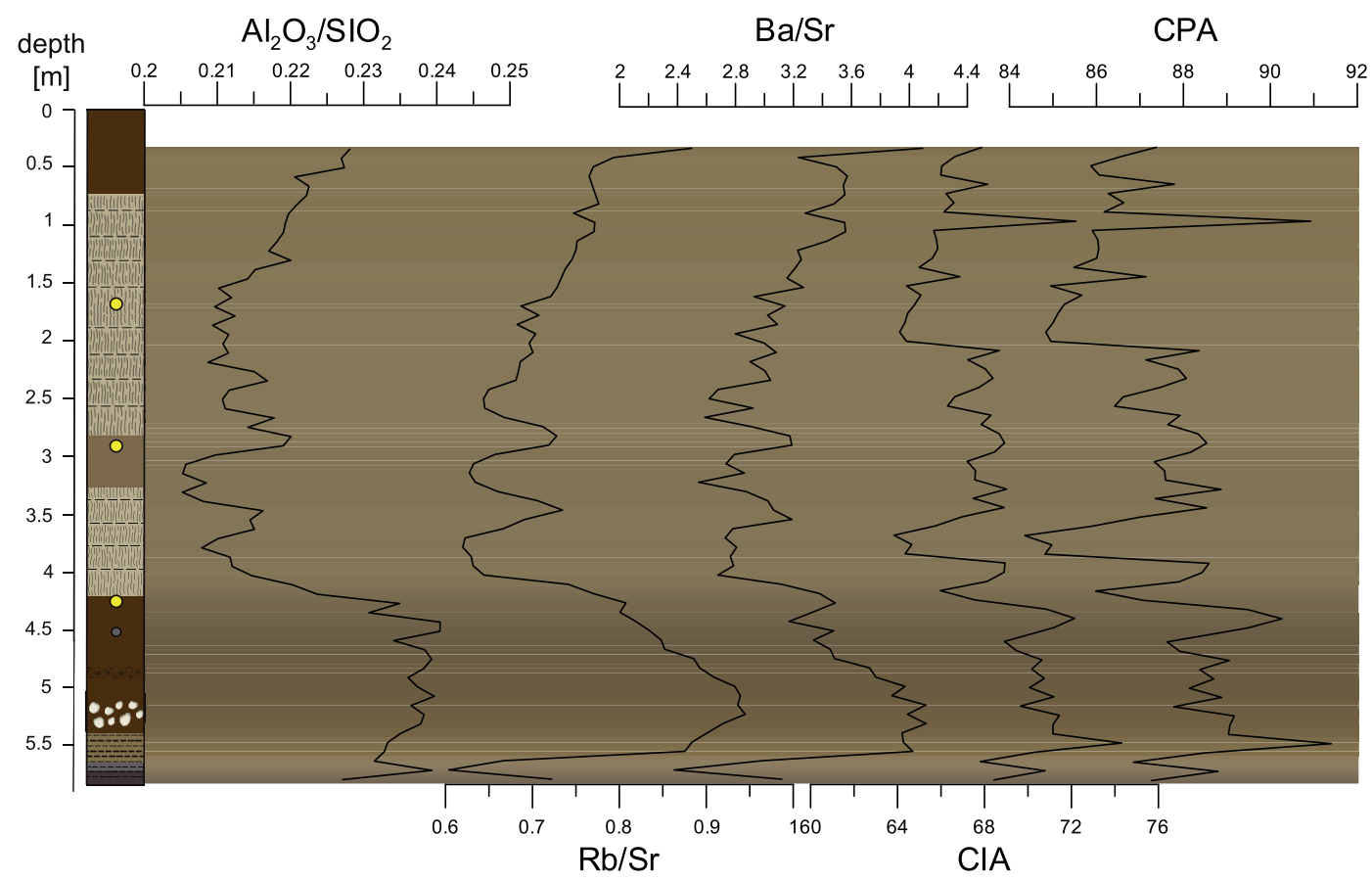

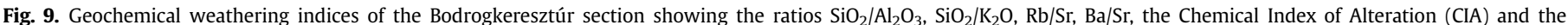
Chemical Proxy of Alteration (CPA).

higher (Basarin et al., 2014; Buggle et al., 2014; Marković et al., 2014). The values of the close-by Tokaj section are notably lower, but still higher than other sections in the Carpathian Basin (Basarin et al., 2014; Buggle et al., 2014; Marković et al., 2014; Zeeden et al., 2016b). High $\chi$ and $\chi_{\mathrm{fd}}$ for loess sediments, supported by low $\mathrm{L}^{*}$, high $\mathrm{a}^{*}$ values and low $\mathrm{CaO}$ content, proves generally wetter/milder conditions at the Kopasz Hill also during periods of loess formation.

Although milder conditions at the Bodrogkeresztúr section are recorded, two layers at $\sim 280-320 \mathrm{~cm}$ and $\sim 360-390 \mathrm{~cm}$ clearly show a high contribution of coarse particles indicating rather high wind intensities or a shorter transport distance (cf. Fig. 6). These layers may relate to Heinrich Events 3 and/or 2, reported from (south)eastern European loess (Shi et al., 2003; Sümegi et al., 2012; Zeeden et al., 2016a). In particular, Heinrich event 2 has been suggested to be associated with high eolian sedimentation rates (Bokhorst et al., 2011). Although the possible events might be covered by the OSL ages of samples C-L3795 and C-L3797, the large uncertainties of the age estimates do not allow 


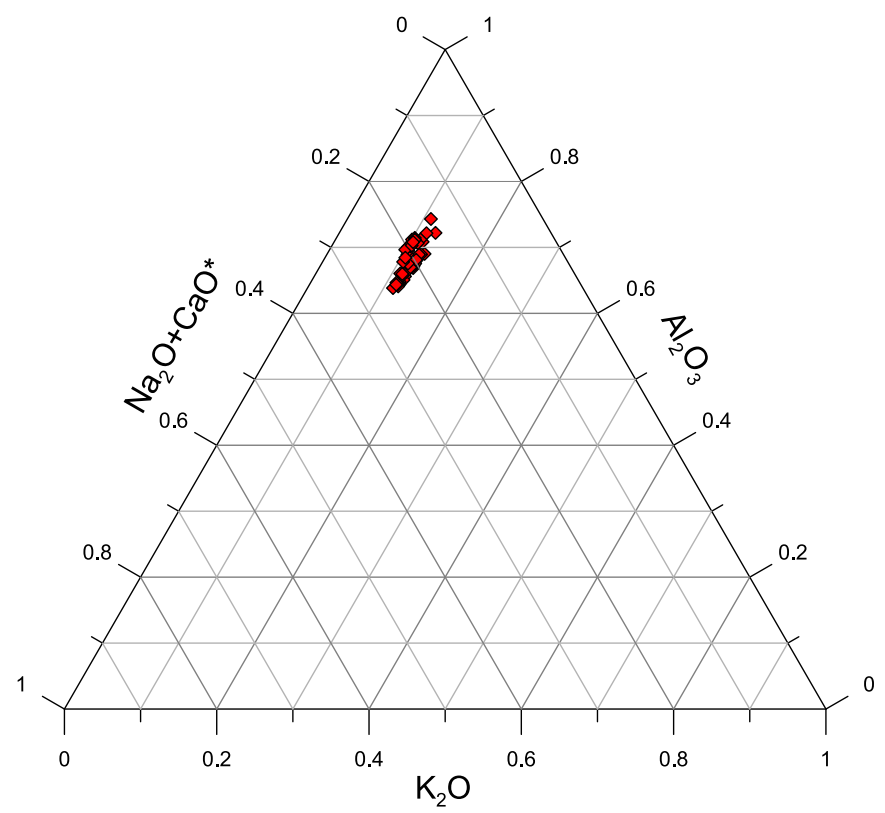

Fig. 10. A-CN-K diagram. Sample distribution in the diagram indicates domination of silicate weathering.

a straightforward assignment. In the lower layer with high coarse particles content, all other proxies show low values $\left(\chi, \chi_{\mathrm{fd}}, \mathrm{a}^{*}\right.$ and weathering indices) indicating cold and dry conditions. The layer with high content of coarse particles between $\sim 280$ and $320 \mathrm{~cm}$ is represented by indications of a weak paleosol development. Moreover, $\chi$ and $\chi_{\mathrm{fd}}$ do show a slight decrease, but $\chi_{\mathrm{fd}}$ is still generally high for MIS 2 loess (Fig. 4). This indicates that the general soil humidity was still relatively high, while the eolian dynamics were more intensive or the source area was characterized by coarser particles (e.g. due to stronger river discharge). At the Tokaj section, modeling results of n-alkanes suggest MIS 2 as a period with higher soil moisture, but two dry periods are also observed (Schatz et al., 2011). Relying only on the luminescence dating it is challenging to conclude if those two layers of dryer conditions at the Tokaj section are related to two layers with higher sand content at the Bodrogkeresztúr section. However, the vicinity and consistency of their occurrence suggests so. The data presented in our study points towards a more widely occurring signal related to north Atlantic cold events.

The loess at BKT shows a generally homogeneous geochemical composition. However, a part of the profile between $\sim 210$ and $280 \mathrm{~cm}$ shows surprisingly high $\mathrm{Cl}$ values (cf. Fig. 8). Such high $\mathrm{Cl}$ values may be related to a tephra layer (Obreht et al., 2016), but no glass shards were found after detailed microscopic sample examination. This may indicate further contribution from an additional or different source during the formation of this loess layer, and suggests a change in sediment properties. Moreover, the characteristic stratigraphic shape of the anomaly with an abrupt but low amplitude, beginning and a following increase ending in a maximum peak, which is abruptly ceased, speaks for the relocation of parental material with high $\mathrm{Cl}$ content. A different geochemical composition suggesting an additional source is further supported by the opposing trends of $\chi$ and $\chi_{\mathrm{fd}}$, suggesting that the contribution from the additional source might have had a higher bulk $\chi$ than the main source area, while the climatic conditions were unfavorable for the formation of fine magnetic grains and $\chi_{\mathrm{fd}}$ decreased. Without further proof we refrain from a more in depth interpretation.

\subsection{Erosion of uppermost loess (late MIS2)}

Another interesting feature of the section investigated at the Kopasz Hill is that the upper loess deposition seems to have ended around $20 \mathrm{ka}$ or was eroded and/or overprinted by Holocene pedogenesis (Schatz et al., 2012). Although we did not date the uppermost part of the profile, one can assume a similar behavior at Bodrogkeresztúr, since sample C-L3799 can be considered rather old in comparison to its depth of $1.69 \mathrm{~m}$. It is noteworthy that stratigraphy and ages compare well between Bodrogkeresztúr and Tokaj, although the geomorphological setting is different (this study: position low in the landscape on the northern side of the Kopasz Hill vs. Schatz et al.: position higher in the landscape on the eastern side of the same hill). For an impression of the section, see also the photograph in Supplementary Fig. S5.

\section{Conclusion}

The investigated loess-paleosol sequence in northeastern Hungary was dated to $33.5 \pm 2.5-28.0 \pm 2.1 \mathrm{ka}$ and $\sim 2.5 \mathrm{~m}$ of loess accumulation in the dated time frame. While the lowermost part needs to be disregarded in the paleoclimatological investigation due to the (partial) input of alluvial sediment, the remaining section shows several interesting features. It is suggested that the loess originates dominantly from the Tisza River floodplain and that sediment was transported predominantly from a north-eastern direction. We conclude that the general climatic conditions during the late MIS 3 and early MIS 2 were more humid than in most of the Carpathian Basin. However, short relatively dry periods are recorded as well. This supports an overall observation based on mollusk results from the Carpathian Basin that the northern part was more humid (but colder), and that the paleoenvironmental evolution was more dynamic (Rudner and Sümegi, 2001; Sümegi and Krolopp, 2002; Bösken et al., accepted). Temperatures were higher and the relative humidity was lower in the southern Carpathian Basin, suggesting steppic environmental conditions (Marković et al., 2007, 2015). Additionally, we highlight that the foothill areas apparently provided unique microclimatic conditions in the Carpathian Basin that were more humid and had higher biomass production than in the basin itself, at least during the last 30-50 ka (also supported by Schatz et al., 2011). This may be related to an increased occurrence of Upper Paleolithic findings along the foothill areas around the Carpathian Basin, as suggested for the Aurignacian (e.g. Floss et al., 2016), supporting a more favorable environment in these elevated positions. Also, Sümegi et al. (2016) point out that the local environment of the oldest Gravettian sites occur along creek valleys and mixed taiga woodlands and loess-covered hills of spruce and steppe forests. The absence of discovered artifacts outside of the foothill area and the occurrence of camp sites repeatedly within spruce forests within this period (Sümegi et al., 2016), may be interpreted as highlighting a selective preference of the Gravettian population for these environments.

\section{Acknowledgments}

The investigations were carried out within CRC 806 "Our way to Europe", subproject B1 "The Eastern Trajectory: Last Glacial Paleogeography and Archaeology of the Eastern Mediterranean and of the Balkan Peninsula", supported by the DFG (Deutsche Forschungsgemeinschaft, grant number INST 216/596-2). All physical and chemical data obtained in this study are available in the CRC806 database (see Bösken et al., 2017c). We thank Anja Zander for the assessment of the radionuclide concentrations and her help in the Cologne Luminescence Laboratory. We thank Marianne 
Dohms and her team from the sedimentological Laboratory at the RWTH Aachen University for the measurements of the sedimentological and geochemical samples. Further, the authors would like to thank David Molnar and Balázs Sümegi for help during fieldwork, and Philipp Schulte and Daniel Veres for fruitful discussions. Finally, we thank Wei Chu for his assistance in the field, his advice on the manuscript and the preparation of the radiocarbon sample.

\section{Appendix A. Supplementary data}

Supplementary data related to this article can be found at https://doi.org/10.1016/j.quaint.2017.12.008.

\section{References}

Auclair, M., Lamothe, M., Huot, S., 2003. Measurement of anomalous fading for feldspar IRSL using SAR. Radiat. Meas. 37, 487-492. https://doi.org/10.1016/ S1350-4487(03)00018-0.

Bábek, O., Chlachula, J., Grygar, T.M., 2011. Non-magnetic indicators of pedogenesis related to loess magnetic enhancement and depletion: examples from the Czech Republic and southern Siberia. Quat. Sci. Rev. 30, 967-979. https:// doi.org/10.1016/j.quascirev.2011.01.009.

Basarin, B., Buggle, B., Hambach, U., Marković, S.B., Dhand, K.O., Kovačević, A. Stevens, T., Guo, Z., Lukić, T., 2014. Time-scale and astronomical forcing of Serbian loess-paleosol sequences. Glob. Planet. Change 122, 89-106. https:/| doi.org/10.1016/j.gloplacha.2014.08.007.

Baumgart, P., Hambach, U., Meszner, S., Faust, D., 2013. An environmental magnetic fingerprint of periglacial loess: records of Late Pleistocene loess-palaeosol sequences from Eastern Germany. Quat. Int. 296, 82-93. https://doi.org/10.1016 j.quaint.2012.12.021.

Bell, W.T., 1980. Alpha dose attenuation in quartz grains for thermoluminescence dating. Anc. TL 12, 4-8.

Bokhorst, M.P., Vandenberghe, J., Sümegi, P., Łanczont, M., Gerasimenko, N.P., Matviishina, Z.N., Marković, S.B., Frechen, M., 2011. Atmospheric circulation patterns in central and eastern Europe during the Weichselian Pleniglacial inferred from loess grain-size records. Quat. Int. 234, 62-74. https://doi.org/ 10.1016/j.quaint.2010.07.018.

Bösken, J., Klasen, N., Zeeden, C., Obreht, I., Markovic, S.B., Hambach, U., Lehmkuhl, F., 2017. New luminescence-based geochronology framing the last two glacial cycles at the southern limit of European Pleistocene loess in Stalać. Geochronometria 44, 150-161. https://doi.org/10.1515/geochr-2015-0062.

Bösken, J., Sümegi, P., Zeeden, C., Klasen, N., Gulyás, S., Lehmkuhl, F., 2017. Investigating the last glacial Gravettian site "Ságvár Lyukas Hill" (Hungary) and its paleoenvironmental and geochronological context using a multi-proxy approach. Palaeogeogr. Palaeoclimatol. Palaeoecol. https://doi.org/10.1016 j.palaeo.2017.08.010 (in press).

Bösken, J., Zeeden, C., Klasen, N., Obreht, I., Hambach, U., Sümegi, P., Lehmkuhl, F., 2017c. Paleoclimatic Proxy Data from the MIS3/2 Transition Recorded at the Bodrogkeresztúr Loess-paleosol Sequence in Northeast Hungary. CRC806Database. https://doi.org/10.5880/SFB806.38.

Bradák, B., 2009. Application of anisotropy of magnetic susceptibility (AMS) for the determination of paleo-wind directions and paleo-environment during the accumulation period of Bag Tephra, Hungary. Quat. Int. 198, 77-84. https:// doi.org/10.1016/j.quaint.2007.11.005.

Buggle, B., Glaser, B., Zöller, L., Hambach, U., Marković, S., Glaser, I., Gerasimenko, N. 2008. Geochemical characterization and origin of southeastern and Eastern European loesses (Serbia, Romania, Ukraine). Quat. Sci. Rev. 27, 1058-1075. https://doi.org/10.1016/j.quascirev.2008.01.018.

Buggle, B., Hambach, U., Glaser, B., Gerasimenko, N., Marković, S.B., Glaser, I., Zöller, L., 2009. Stratigraphy, and spatial and temporal paleoclimatic trends in Southeastern/Eastern European loess-paleosol sequences. Quat. Int. 196, 86-106. https://doi.org/10.1016/j.quaint.2008.07.013.

Buggle, B., Glaser, B., Hambach, U., Gerasimenko, N., Marković, S., 2011a. An evaluation of geochemical weathering indices in loess-paleosol studies. Quat. Int 240, 12-21. https://doi.org/10.1016/j.quaint.2010.07.019.

Buggle, B., Glaser, B., Hambach, U., Gerasimenko, N., Marković, S., 2011b. An evaluation of geochemical weathering indices in loess-paleosol studies. Quat. Int. 240, 12-21. https://doi.org/10.1016/j.quaint.2010.07.019.

Buggle, B., Hambach, U., Kehl, M., Marković, S.B., Zöller, L., Glaser, B., 2013. The progressive evolution of a continental climate in southeast-central European lowlands during the Middle Pleistocene recorded in loess paleosol sequences. Geology 41, 771-774. https://doi.org/10.1130/G34198.1.

Buggle, B., Hambach, U., Müller, K., Zöller, L., Marković, S.B., Glaser, B., 2014. Iron mineralogical proxies and Quaternary climate change in SE-European loess-paleosol sequences. CATENA 117, 4-22. https://doi.org/10.1016/ j.catena.2013.06.012.

Buylaert, J.-P., Jain, M., Murray, A.S., Thomsen, K.J., Thiel, C., Sohbati, R., 2012 A robust feldspar luminescence dating method for Middle and Late Pleistocene sediments: Feldspar luminescence dating of Middle and Late Pleistocene sediments. Boreas 41, 435-451. https://doi.org/10.1111/j.1502-3885.2012.00248.x.
Chu, W., Lengyel, G., Zeeden, C., Pentek, A., Kaminská, L., Mester, Z., 2017. Evaluating upper paleolithic surface collections from loess-like sediments in the Northern Carpathian Basin. Quat. Int. https://doi.org/10.1016/j.quaint.2017.05.017 (in press)

Conard, N.J., Bolus, M., 2003. Radiocarbon dating the appearance of modern humans and timing of cultural innovations in Europe: new results and new challenges. J. Hum. Evol. 44, 331-371. https://doi.org/10.1016/S0047-2484(02) 00202-6.

Conard, N.J., Bolus, M., 2008. Radiocarbon dating of the late Middle Paleolithic and the Aurignacian of the Swabian Jura. J. Hum. Evol. 55, 886-897. https://doi.org/ 10.1016/j.jhevol.2008.08.006.

Constable, C., Tauxe, L., 1990. The bootstrap for magnetic susceptibility tensors. J. Geophys. Res. 95, 8383-8395. https://doi.org/10.1029/JB095iB06p08383.

Derbyshire, E., 2003. Loess, and the dust indicators and records of terrestrial and marine palaeoenvironments (DIRTMAP) database. Quat. Sci. Rev. 22, 1813-1819. https://doi.org/10.1016/S0277-3791(03)00209-9.

Dobosi, V.T. (Ed.), 2000. Bodrogkeresztúr - Henye (NE Hungary) Upper Palaeolithic Site. Magyar Nemzeti Múzeum Kiadványa, Budapest.

Durcan, J.A., King, G.E., Duller, G.A.T., 2015. DRAC: dose rate and age calculator for trapped charge dating. Quat. Geochronol. 28, 54-61. https://doi.org/10.1016/ j.quageo.2015.03.012.

Evans, M.E., Heller, F., 2001. Magnetism of loess/palaeosol sequences: recent developments. Earth Sci. Rev. 54, 129-144. https://doi.org/10.1016/S00128252(01)00044-7.

Floss, H., Fröhle, S., Wettengl, S., 2016. The aurignacian along the danube - its twoFold role as a Transalpine and Cisalpine passageway of early Homo Sapiens into Europe. In: Krauss, R., Floss, H. (Eds.), Proceedings of the International Workshop within the Collaborative Research Centres Sfb 1070 "RessourcenKulturen", Schloss Hohentübingen, 9th of May 2014. Presented at the Southeast Europe before Neolithisation. Universität Tübingen, pp. 13-39.

Guérin, G., Mercier, N., Nathan, R., Adamiec, G., Lefrais, Y., 2012. On the use of the infinite matrix assumption and associated concepts: a critical review. Radiat. Meas. 47, 778-785. https://doi.org/10.1016/j.radmeas.2012.04.004.

Guo, Z.T., Ruddiman, W.F., Hao, Q.Z., Wu, H.B., Qiao, Y.S., Zhu, R.X., Peng, S.Z., Wei, J.J., Yuan, B.Y., Liu, T.S., 2002. Onset of Asian desertification by $22 \mathrm{Myr}$ ago inferred from loess deposits in China. Nature 416, 159-163. https://doi.org/10.1038/ 416159a.

Hao, Q., Oldfield, F., Bloemendal, J., Guo, Z., 2008. Particle size separation and evidence for pedogenesis in samples from the Chinese Loess Plateau spanning the past 22 my. Geology 36, 727-730.

Hauck, T.C., Lehmkuhl, F., Zeeden, C., Bösken, J., Thiemann, A., Richter, J., 2017. The Aurignacian way of life: Contextualizing early modern human adaptation in the Carpathian Basin. Quat. Int. https://doi.org/10.1016/j.quaint.2017.10.020 (in press).

Heller, F., Liu, T., 1984. Magnetism of Chinese loess deposits. Geophys. J. Int. 77, 125-141. https://doi.org/10.1111/j.1365-246X.1984.tb01928.x.

Hošek, J., Hambach, U., Lisá, L., Grygar, T.M., Horáček, I., Meszner, S., Knésl, I., 2015. An integrated rock-magnetic and geochemical approach to loess/paleosol sequences from Bohemia and Moravia (Czech Republic): implications for the Upper Pleistocene paleoenvironment in central Europe. Palaeogeogr. Palaeoclimatol. Palaeoecol. 418, 344-358. https://doi.org/10.1016/j.palaeo.2014.11.024.

Huntley, D.J., Baril, M.R., 1997. The K content of the K-feldspars being measured in optical dating or in thermoluminescence dating. Anc. TL 15, 11-12.

Huntley, D.J., Hancock, R.G.V., 2001. The Rb contents of the K-feldspar grains being measured in optical dating. Anc. TL 19, 43-46.

Iovita, R., Doboş, A., Fitzsimmons, K.E., Probst, M., Hambach, U., Robu, M., Vlaicu, M., Petculescu, A., 2014. Geoarchaeological prospection in the loess steppe: preliminary results from the lower danube Survey for paleolithic sites (LoDanS). Quat. Int. 351, 98-114. https://doi.org/10.1016/j.quaint.2013.05.018.

ISO International Standard 13320, 2009. Particle Size Analysis — Laser Diffraction Methods.

Jelinek, V., 1977. The Statistical Theory of Measuring Anisotropy of Magnetic Susceptibility of Rocks and its Application. Geofyzika. Brno 87, 4.

Kels, H., Protze, J., Sitlivy, V., Hilgers, A., Zander, A., Anghelinu, M., Bertrams, M., Lehmkuhl, F., 2014. Genesis of loess-like sediments and soils at the foothills of the Banat Mountains, Romania - examples from the paleolithic sites Românești and Coşava. Quat. Int. 351, 213-230. https://doi.org/10.1016/j.quaint.2014.04.063.

Krauß, L., Zens, J., Zeeden, C., Schulte, P., Eckmeier, E., Lehmkuhl, F., 2016. A multiproxy analysis of two loess-paleosol sequences in the Northern Harz Foreland, Germany. Palaeogeogr. Palaeoclimatol. Palaeoecol. 461, 401-417. https:// doi.org/10.1016/j.palaeo.2016.09.001.

Kukla, G., Heller, F., Ming, L.X., Chun, X.T., Sheng, L.T., Sheng, A.Z., 1988. Pleistocene climates in China dated by magnetic susceptibility. Geology 16, 811-814. https://doi.org/10.1130/0091-7613(1988)016<0811:PCICDB > 2.3.CO;2.

Kukla, G.J., 1977. Pleistocene land-sea correlations I. Europe. Earth-Science Rev. 13, 307-374. https://doi.org/10.1016/0012-8252(77)90125-8.

Liritzis, I., Stamoulis, K., Papachristodoulou, C., Ioannides, K., 2013. A re-evaluation of radiation dose-rate conversion factors. Mediterr. Archaeol. Archaeom. 13, $1-15$.

Lukić, T., Basarin, B., Buggle, B., Markovič, S.B., Tomović, V.M., Raljič, J.P., Hrnjak, I., Timar-Gabor, A., Hambach, U., Gavrilov, M.B., 2014. A joined rock magnetic and colorimetric perspective on the Late Pleistocene climate of Orlovat loess site (Northern Serbia). Quat. Int. 334-335, 179-188. https://doi.org/10.1016/ j.quaint.2014.03.042.

Marković, S.B., Oches, E.A., McCoy, W.D., Frechen, M., Gaudenyi, T., 2007. 
Malacological and sedimentological evidence for "warm" glacial climate from the Irig loess sequence, Vojvodina, Serbia. Geochem. Geophys. Geosyst. 8, Q09008. https://doi.org/10.1029/2006GC001565.

Marković, S.B., Hambach, U., Stevens, T., Kukla, G.J., Heller, F., McCoy, W.D., Oches, E.A., Buggle, B., Zöller, L., 2011. The last million years recorded at the Stari Slankamen (Northern Serbia) loess-palaeosol sequence: revised chronostratigraphy and long-term environmental trends. Quat. Sci. Rev. 30, 1142-1154. https://doi.org/10.1016/j.quascirev.2011.02.004.

Marković, S.B., Timar-Gabor, A., Stevens, T., Hambach, U., Popov, D., Tomić, N., Obreht, I., Jovanović, M., Lehmkuhl, F., Kels, H., Marković, R., Gavrilov, M.B., 2014. Environmental dynamics and luminescence chronology from the Orlovat loess-palaeosol sequence (Vojvodina, northern Serbia). J. Quat. Sci. 29, 189-199. https://doi.org/10.1002/jqs.2693.

Marković, S.B., Stevens, T., Kukla, G.J., Hambach, U., Fitzsimmons, K.E., Gibbard, P., Buggle, B., Zech, M., Guo, Z., Hao, Q., Wu, H., O'Hara Dhand, K., Smalley, I.J., Újvári, G., Sümegi, P., Timar-Gabor, A., Veres, D., Sirocko, F., Vasiljević, D.A., Jary, Z., Svensson, A., Jović, V., Lehmkuhl, F., Kovács, J., Svirčev, Z., 2015. Danube loess stratigraphy - towards a pan-European loess stratigraphic model. EarthScience Rev. 148, 228-258. https://doi.org/10.1016/j.earscirev.2015.06.005.

Mellars, P., 2011. Palaeoanthropology: the earliest modern humans in Europe. Nature 479, 483-485. https://doi.org/10.1038/479483a.

Muhs, D.R., Bettis III, E.A., Roberts, H.M., Harlan, S.S., Paces, J.B., Reynolds, R.L., 2013. Chronology and provenance of last-glacial (Peoria) loess in western Iowa and paleoclimatic implications. Quat. Res. 80, 468-481. https://doi.org/10.1016/ j.yqres.2013.06.006.

Nawrocki, J., Polechońska, O., Boguckij, A., Łanczont, M., 2006. Palaeowind directions recorded in the youngest loess in Poland and western Ukraine as derived from anisotropy of magnetic susceptibility measurements. Boreas 35 , 266-271. https://doi.org/10.1080/03009480600584907.

Nesbitt, H.W., Young, G.M., 1989. Formation and diagenesis of weathering profiles. J. Geol. 129-147. https://doi.org/10.1086/629290.

Nesbitt, H.W., Young, G.M., 1984. Prediction of some weathering trends of plutonic and volcanic rocks based on thermodynamic and kinetic considerations. Geochim. Cosmochim. Acta 48, 1523-1534. https://doi.org/10.1016/0016-7037(84) 90408-3.

Nottebaum, V., Lehmkuhl, F., Stauch, G., Lu, H., Yi, S., 2015. Late Quaternary aeolian sand deposition sustained by fluvial reworking and sediment supply in the Hexi Corridor - an example from northern Chinese drylands. Geomorphology 250, 113-127. https://doi.org/10.1016/j.geomorph.2015.08.014.

Obreht, I., Buggle, B., Catto, N., Marković, S.B., Bösel, S., Vandenberghe, D.A.G., Hambach, U., Svirčev, Z., Lehmkuhl, F., Basarin, B., Gavrilov, M.B., Jović, G., 2014. The Late Pleistocene Belotinac section (southern Serbia) at the southern limit of the European loess belt: environmental and climate reconstruction using grain size and stable $C$ and $\mathrm{N}$ isotopes. Quat. Int. 334-335, 10-19. https://doi.org/ 10.1016/j.quaint.2013.05.037.

Obreht, I., Zeeden, C., Schulte, P., Hambach, U., Eckmeier, E., Timar-Gabor, A., Lehmkuhl, F., 2015. Aeolian dynamics at the Orlovat loess-paleosol sequence, northern Serbia, based on detailed textural and geochemical evidence. Aeolian Res. 18, 69-81. https://doi.org/10.1016/j.aeolia.2015.06.004.

Obreht, I., Zeeden, C., Hambach, U., Veres, D., Marković, S.B., Bösken, J., Svirčev, Z., Bačević, N., Gavrilov, M.B., Lehmkuhl, F., 2016. Tracing the influence of Mediterranean climate on Southeastern Europe during the past 350,000 years. Sci. Rep. 6, 36334. https://doi.org/10.1038/srep36334.

Obreht, I., Hambach, U., Veres, D., Zeeden, C., Bösken, J., Stevens, T., Marković, S.B., Klasen, N., Brill, D., Burow, C., Lehmkuhl, F., 2017. Shift of large-scale atmospheric systems over Europe during late MIS 3 and implications for Modern Human dispersal. Sci. Rep. 7, 5848. https://doi.org/10.1038/s41598-017-06285$\mathrm{X}$.

Özer, M., Orhan, M., Işik, N.S., 2010. Effect of particle optical properties on size distribution of soils obtained by laser diffraction. Environ. Eng. Geosci. 16, 163-173. https://doi.org/10.2113/gseegeosci.16.2.163.

Pécsi, M., Richter, G., 1996. Loess - Herkunft - Gliederung - Landschaften. Z. Geomorphol. 391. Supplementary Issues 98.

Prescott, J.R., Hutton, J.T., 1994. Cosmic ray contribution to dose rates for luminescence and ESR dating - large depths and long-term variations. Radiat. Meas. 23, 497-500.

Reimer, P.J., Bard, E., Bayliss, A., Beck, J.W., Blackwell, P.G., Ramsey, C.B., Buck, C.E., Cheng, H., Edwards, R.L., Friedrich, M., Grootes, P.M., Guilderson, T.P., Haflidason, H., Hajdas, I., Hatté, C., Heaton, T.J., Hoffmann, D.L., Hogg, A.G., Hughen, K.A., Kaiser, K.F., Kromer, B., Manning, S.W., Niu, M., Reimer, R.W., Richards, D.A., Scott, E.M., Southon, J.R., Staff, R.A., Turney, C.S.M., Plicht, J. van der, 2013. IntCal13 and Marine13 radiocarbon age calibration curves 0-50,000 Years cal BP. Radiocarbon 55, 1869-1887. https://doi.org/10.2458/azu_js_ rc.55.16947.

Rudner, Z.E., Sümegi, P., 2001. Recurring taiga forest-steppe habitats in the Carpathian Basin in the upper Weichselian. Quat. Int. 76-77, 177-189. https:// doi.org/10.1016/S1040-6182(00)00101-4.

Schäfer, A., 2005. Klastische Sedimente - Fazies und Sequenzstratigraphie. Springer Spektrum.

Schatz, A.-K., Zech, M., Buggle, B., Gulyás, S., Hambach, U., Marković, S.B., Sümegi, P., Scholten, T., 2011. The late Quaternary loess record of Tokaj, Hungary: reconstructing palaeoenvironment, vegetation and climate using stable $\mathrm{C}$ and $\mathrm{N}$ isotopes and biomarkers. Quat. Int. 240, 52-61. https://doi.org/10.1016/ j.quaint.2010.10.009.

Schatz, A.-K., Buylaert, J.-P., Murray, A., Stevens, T., Scholten, T., 2012. Establishing a luminescence chronology for a palaeosol-loess profile at Tokaj (Hungary): a comparison of quartz OSL and polymineral IRSL signals. Quat. Geochronol. 10, 68-74. https://doi.org/10.1016/j.quageo.2012.02.018.

Schatz, A.-K., Scholten, T., Kühn, P., 2015. Paleoclimate and weathering of the Tokaj (Hungary) loess-paleosol sequence. Palaeogeogr. Palaeoclimatol. Palaeoecol. 426, 170-182. https://doi.org/10.1016/j.palaeo.2015.03.016.

Schulte, P., Lehmkuhl, F., Steininger, F., Loibl, D., Lockot, G., Protze, J., Fischer, P., Stauch, G., 2016. Influence of $\mathrm{HCl}$ pretreatment and organo-mineral complexes on laser diffraction measurement of loess-paleosol-sequences. CATENA 137, 392-405. https://doi.org/10.1016/j.catena.2015.10.015.

Shi, C., Zhu, R., Glass, B.P., Liu, Q., Zeman, A., Suchy, V., 2003. Climate variations since the last interglacial recorded in Czech loess. Geophys. Res. Lett. 30 https:// doi.org/10.1029/2003GL017251.

Smalley, I.J., Vita-Finzi, C., 1968. Formation of Fine particles in Sandy deserts and nature of desert loess. J. Sediment. Pet. 38, 766-774. https://doi.org/10.1306/ 74D71A69-2B21-11D7-8648000102C1865D.

Smalley, I.J., Leach, J.A., 1978. The origin and distribution of the loess in the Danube basin and associated regions of East-Central Europe - a review. Sediment. Geol. 21,1-26. https://doi.org/10.1016/0037-0738(78)90031-3.

Sprafke, T., 2016. Löss in Niederösterreich - Archiv quartärer Klima- und Landschaftsveränderungen. Würzburg University Press, Würzburg.

Stevens, T., Marković, S.B., Zech, M., Hambach, U., Sümegi, P., 2011. Dust deposition and climate in the Carpathian Basin over an independently dated last glacial-interglacial cycle. Quat. Sci. Rev. 30, 662-681. https://doi.org/10.1016/ j.quascirev.2010.12.011.

Sümegi, P., 2005. Loess and Upper Paleolithic Environment in Hungary: An Introduction to the Environmental History of Hungary. Aurea Kiadó, Nagykovácsi.

Sümegi, P., Hertelendi, E., 1998. Reconstruction of microenvironmental changes in Kopasz Hill loess area at Tokaj (Hungary) between 15,000-70,000 BP years. Radiocarbon 40, 855-863.

Sümegi, P., Krolopp, E., 2000. Palaeoecological reconstruction of the Ságvár-Lascaux interstadial. ERAUL 95, 103-112.

Sümegi, P., Krolopp, E., 2002. Quatermalacological analyses for modeling of the upper Weichselian palaeoenvironmental changes in the Carpathian Basin. Quat. Int. 91, 53-63. https://doi.org/10.1016/S1040-6182(01)00102-1.

Sümegi, P., Rudner, Z.E., 2001. In situ charcoal fragments as remains of natural wild fires in the upper Würm of the Carpathian Basin. Quat. Int. 76/77, 165-176. https://doi.org/10.1016/S1040-6182(00)00100-2.

Sümegi, P., Krolopp, E., Hertelendi, E., 1998. A Ságvár-Lascaux interstadiális öskörnyezeti rekonstrukciója. [Palaeoecological reconstruction of the SágvárLascaux interstadial]. Acta Geogr. Geol. Meteorol. Debrecina 34, 65-180.

Sümegi, P., Rudner, E., Beszeda, I., 2000. Stratigraphical and palaeoecological investigation of the fossil soil comprising Upper Palaeolithic tools at Bodrogkeresztúr - Henye. In: Dobosi, T.V. (Ed.), Bodrogkeresztúr - Henye (NE Hungary) Upper Palaeolithic Site. Magyar Nemzeti Múzeum Kiadványa, Budapest, pp. 217-220.

Sümegi, P., Gulyás, S., Csökmei, B., Molnár, D., Hambach, U., Stevens, T., Markovic, S.B., Almond, P.C., 2012. Climatic fluctuations inferred for the Middle and Late Pleniglacial (MIS 2) based on high-resolution (ca. 20 y) preliminary environmental magnetic investigation of the loess section of the Madaras brickyard (Hungary). Cent. Eur. Geol. 55, 329-345. https://doi.org/10.1556/ CEuGeol.55.2012.3.6.

Sümegi, P., Töröcsik, T., Náfrádi, K., Sümegi, B., Majkut, P., Molnár, D., Tapody, R., 2016. Radiocarbon dated complex paleoecological and geoarcheological analyses at the Bodrogkeresztúr-Henye Gravettian Site (NE Hungary). Archeometriai Múhely XIII (1).

Sun, Y., An, Z., Clemens, S.C., Bloemendal, J., Vandenberghe, J., 2010. Seven million years of wind and precipitation variability on the Chinese Loess Plateau. Earth Planet. Sci. Lett. 297, 525-535. https://doi.org/10.1016/j.epsl.2010.07.004.

Talma, A.S., Vogel, J.C., 1993. A simplified approach to calibrating 14 C dates. Radiocarbon 35, 317-322.

Thiel, C., Buylaert, J.-P., Murray, A., Terhorst, B., Hofer, I., Tsukamoto, S., Frechen, M. 2011. Luminescence dating of the Stratzing loess profile (Austria) - testing the potential of an elevated temperature post-IR IRSL protocol. Quat. Int. 234, 23-31. https://doi.org/10.1016/j.quaint.2010.05.018.

Újvári, G., Varga, A., Balogh-Brunstad, Z., 2008. Origin, weathering, and geochemical composition of loess in southwestern Hungary. Quat. Res. 69, 421-437. https:// doi.org/10.1016/j.yqres.2008.02.001.

Újvári, G., Kovács, J., Varga, G., Raucsik, B., Marković, S.B., 2010. Dust flux estimates for the Last Glacial Period in East Central Europe based on terrestrial records of loess deposits: a review. Quat. Sci. Rev. 29, 3157-3166. https://doi.org/10.1016/ j.quascirev.2010.07.005.

Újvári, G., Varga, A., Ramos, F.C., Kovács, J., Németh, T., Stevens, T., 2012. Evaluating the use of clay mineralogy, $\mathrm{Sr}-\mathrm{Nd}$ isotopes and zircon $\mathrm{U}-\mathrm{Pb}$ ages in tracking dust provenance: an example from loess of the Carpathian Basin. Chem. Geol. 304-305, 83-96. https://doi.org/10.1016/j.chemgeo.2012.02.007.

Újvári, G., 2014. Interactive comment on "Paleoclimate and weathering of the Tokaj (NE Hungary) loess-paleosol sequence: a comparison of geochemical weathering indices and paleoclimate parameters" by A.-K. Schatz et al. Clim. Past Discuss. 10, C19-C26.

Újvári, G., Molnár, M., Novothny, Á., Páll-Gergely, B., Kovács, J., Várhegyi, A., 2014a. AMS $14 \mathrm{C}$ and OSL/IRSL dating of the Dunaszekcső loess sequence (Hungary): chronology for 20 to $150 \mathrm{ka}$ and implications for establishing reliable age-depth models for the last 40 ka. Quat. Sci. Rev. 106, 140-154. https:// doi.org/10.1016/j.quascirev.2014.06.009. 
Újvári, G., Varga, A., Raucsik, B., Kovács, J., 2014b. The Paks loess-paleosol sequence: a record of chemical weathering and provenance for the last $800 \mathrm{ka}$ in the midCarpathian Basin. Quat. Int. 319, 22-37. https://doi.org/10.1016/ j.quaint.2012.04.004.

Újvári, G., Kok, J.F., Varga, G., Kovács, J., 2016. The physics of wind-blown loess: implications for grain size proxy interpretations in Quaternary paleoclimate studies. Earth-Science Rev. 154, 247-278. https://doi.org/10.1016/ j.earscirev.2016.01.006.

Varga, A., Újvári, G., Raucsik, B., 2011. Tectonic versus climatic control on the evolution of a loess-paleosol sequence at Beremend, Hungary: an integrated approach based on paleoecological, clay mineralogical, and geochemical data. Quat. Int. 240, 71-86. https://doi.org/10.1016/j.quaint.2010.10.032.

Vértes, L., 1965. Az őskőkor és az átmeneti kőkor emlékei Magyarországon. [The Remains of the Palaeolithic and Mesolithic Ages in Hungary]. Akadémiai Kiadó, Budapest.

Vértes, L., 1966. The upper palaeolithic site on Mt. Henye at Bodrogkeresztúr. Acta Arch. Acad. Sci. Hung 18, 3-14.

Yang, S., Ding, F., Ding, Z., 2006. Pleistocene chemical weathering history of Asian arid and semi-arid regions recorded in loess deposits of China and Tajikistan. Geochim. Cosmochim. Acta 70, 1695-1709. https://doi.org/10.1016/ j.gca.2005.12.012.

Zeeden, C., Hambach, U., Steguweit, L., Anghelinu, M., 2011. Loess stratigraphy using palaeomagnetism: application to the Poiana Cireşului archaeological site (Romania). Quat. Int. 240, 100-107. https://doi.org/10.1016/j.quaint.2010.08.018. Zeeden, C., Hambach, U., Händel, M., 2015. Loess magnetic fabric of the KremsWachtberg archaeological site. Quat. Int. 372, 188-194. https://doi.org/ 10.1016/j.quaint.2014.11.001.

Zeeden, C., Hambach, U., Veres, D., Fitzsimmons, K., Obreht, I., Bösken, J., Lehmkuhl, F., 2016a. Millennial scale climate oscillations recorded in the Lower Danube loess over the last glacial period. Palaeogeogr. Palaeoclimatol. Palaeoecol. https://doi.org/10.1016/j.palaeo.2016.12.029.

Zeeden, C., Kels, H., Hambach, U., Schulte, P., Protze, J., Eckmeier, E., Marković, S.B., Klasen, N., Lehmkuhl, F., 2016b. Three climatic cycles recorded in a loesspalaeosol sequence at Semlac (Romania) - implications for dust accumulation in south-eastern Europe. Quat. Sci. Rev. 154, 130-142. https://doi.org/ 10.1016/j.quascirev.2016.11.002.

Zeeden, C., Krauß, L., Kels, H., Lehmkuhl, F., 2017. Digital image analysis of outcropping sediments: comparison to photospectrometric data from Quaternary loess deposits at Sanovita (Romania) and Achenheim (France). Quat. Int 429 (Part B), 100-107. https://doi.org/10.1016/j.quaint.2016.02.047. 